\title{
UNDERSTANDING THE BLACK-WHITE TEST SCORE GAP IN THE FIRST TWO YEARS OF SCHOOL
}

\author{
Roland G. Fryer, Jr. \\ Steven D. Levitt \\ Working Paper 8975 \\ http://www.nber.org/papers/w8975 \\ NATIONAL BUREAU OF ECONOMIC RESEARCH \\ 1050 Massachusetts Avenue \\ Cambridge, MA 02138 \\ June 2002
}

We are grateful to James Heckman, Susan Mayer, Derek Neal, Meredith Phillips, and Barbara Schneider for helpful comments and suggestions. Financial support provided by the National Science Foundation (Fryer and Levitt). The views expressed herein are those of the authors and not necessarily those of the National Bureau of Economic Research.

(C) 2002 by Roland G. Fryer, Jr. and Steven D. Levitt. All rights reserved. Short sections of text, not to exceed two paragraphs, may be quoted without explicit permission provided that full credit, including (C) notice, is given to the source. 
Understanding The Black-White Test Score Gap in the First Two Years of School

Roland G. Fryer, Jr. and Steven D. Levitt

NBER Working Paper No. 8975

June 2002

JEL No. J15, I20

\begin{abstract}
In previous research, a substantial gap in test scores between White and Black students persists, even after controlling for a wide range of observable characteristics. Using a newly available data set (Early Childhood Longitudinal Study), we demonstrate that in stark contrast to earlier studies, the Black-White test score gap among incoming kindergartners disappears when we control for a small number of covariates. Over the first two years of school, however, Blacks lose substantial ground relative to other races. There is suggestive evidence that differences in school quality may be an important part of the explanation. None of the other hypotheses we test to explain why Blacks are losing ground receive any empirical backing. The difference between our findings and previous research is consistent with real gains made by recent cohorts of Blacks, although other explanations are also possible.
\end{abstract}

Roland G. Fryer, Jr. American Bar Foundation 750 N. Lake Shore Drive Chicago, IL 60611 and University of Chicago roland@uchicago.edu
Steven D. Levitt

Department of Economics

1126 E. 59th Street

University of Chicago

Chicago, IL 60637

and NBER

slevitt@midway.uchicago.edu 
The Black-White test score gap is a robust empirical regularity. A simple comparison of mean test scores typically finds Black students scoring roughly one standard deviation below White students on standardized tests. Even after controlling for a wide range of covariates including family structure, socio-economic status, measures of school quality, and neighborhood characteristics, a substantial racial gap in test scores persists. ${ }^{1}$

Gaining a better understanding of the underlying causes of the test-score gap is a question of great importance. Neal and Johnson (1996) and O'Neill (1990) find that most of the observed Black-White wage differentials among adults disappears once lower eighth grade test scores among Blacks are taken into account. Thus, eliminating the test-score gap that arises by the end of junior high school may be a critical component of reducing racial wage inequality. ${ }^{2}$

A wide variety of possible explanations for the test-score gap have been put forth. These explanations include differences in genetic make-up (Hernstein and Murray, 1984, and Jensen, 1973 and 1998), differences in family structure and poverty (Armor, 1992, Brooks-Gunn and Duncan, 1997, Mayer, 1997, and Phillips et. al., 1998), differences in school quality (Cook and Evans, 2000), racial bias in testing or teachers' perceptions (Delpit, 1995, Ferguson, 1998, and Rodgers and Spriggs, 1996), and differences in culture, socialization, or behavior (Cook and Ludwig, 1998, Fordham and Ogbu, 1986, Fryer, 2002, and Steele and Aronson, 1998). The

${ }^{1}$ See Baughman and Dahlstrom (1968), Bracken, Sabers, and Insko (1987), Brooks-Gunn et. al, (1993, 1994, 1996), Coleman et. al. (1966), Coley (2002), Hernstein and Murray (1994), Humphreys (1988), Jensen (1969, 1973), Kaufman and Kaufman (1983), Krohn and Lamp (1989), Naglieri (1986), Phillips et. al. (1998), Phillips (2000), and Scarr (1981).

${ }^{2}$ To this effect, Christopher Jenks and Meredith Phillips write "Reducing the black-white test score gap would do more to promote racial equality than any other strategy that commands broad political support." 
appropriate public policy choice (if any) to address the test-score gap depends critically on the underlying source of the gap.

In this paper, we utilize the Early Childhood Longitudinal Study Kindergarten Cohort (ECLS-K) to shed new light on the test-score gap. ECLS-K is a new data set administered by the Department of Education. The survey covers a sample of more than 20,000 children entering kindergarten in the fall of 1998. An enormous amount of information is gathered for each individual including family background, school and neighborhood characteristics, teacher and parent assessments, and test scores. The original sample of students has subsequently been reinterviewed in the spring of kindergarten and first grade.

The results we obtain using these new data are informative and in some cases quite surprising. As in previous data sets, we observe substantial racial differences in test scores in the raw data: Black kindergartners score on average .64 standard deviations worse than Whites. In stark contrast to earlier studies (including those looking at kindergartners), however, after controlling for a small number of other observable characteristics (children's age, child's birth weight, a socio-economic status measure, WIC participation, mother's age at first birth, and number of children's books in the home), we essentially eliminate the Black-White test score gap in math and reading for students entering kindergarten. ${ }^{3}$ Controlling for a much larger set of characteristics yields the same conclusion. This same set of covariates accounts for much but not all of the Hispanic-White difference in test scores, but cannot explain the high test-scores of Asians.

${ }^{3}$ On a test of general knowledge, a racial test-score gap persists. On a subjective teacher assessment of general knowledge, however, there is no difference between Blacks and Whites in fall of kindergarten. 
Despite the fact that we see no difference in initial test scores for observationally equivalent Black and White children when they enter kindergarten, their paths diverge once they are in school. Between the beginning of kindergarten and the end of first grade, Black students lose .20 standard deviations relative to White students with similar characteristics. ${ }^{4}$ If the gap in test scores for these children continues to grow at the same rate, by fifth grade the Black students will be .50 standard deviations behind their White counterparts - a gap similar in magnitude to that found in previous analyses (Jones et. al., 1982, Phillips et. al. (1998), and Phillips (2000)).

The leading explanation for the worse trajectory of Black students in our sample is that they attend lower quality schools. When we compare the change in test scores over time for Blacks and Whites attending the same school, Black students lose only a third as much ground as they do relative to Whites in the overall sample. This result suggests that differences in quality across schools attended by Whites and Blacks is likely to be an important part of the story. Interestingly, along "traditional" dimensions of school quality (class size, teacher education, computer:student ratio, etc.), Blacks and Whites attend schools that are similar. On a wide range of "non-standard" school inputs (e.g., gang problems in school, percent of students on free lunch, amount of loitering in front of school by non-students, amount of litter around the school, whether or not students need hall passes, and PTA funding), Blacks do appear to be attending much worse schools after controlling for individual characteristics. ${ }^{5}$ Our story is incomplete,

${ }^{4}$ Neither Hispanics nor Asians experience this widening test score gap over time. Indeed, Hispanic children systematically close the gap relative to Whites, presumably because their initial scores are artificially low as a consequence of limited English proficiency among some Hispanic parents.

${ }^{5}$ This pattern is also consistent with self-selection of low-achieving Whites into schools attended by Blacks. Casting doubt on this alternative explanation is the fact that Whites who go 
however, because the observable differences across schools do little to explain the widening Black-White gap.

We explore a range of other explanations as to why Black children are losing ground, but find very little empirical support for these alternative theories. Black students do not appear to suffer bigger "summer setbacks" when school is not in session. The lower trajectories of Black students is not simply an artifact of standardized testing. Subjective teacher assessments of student performance yield patterns similar to the test-score data. Having a Black teacher provides no benefit to Black students compared to their White classmates, calling into question the possible role of either overt discrimination or low expectations for Black children on the part of White teachers. Finally, adding proxies for behavioral problems does not alter our findings.

The structure of the paper is as follows. Section II provides a brief review of the literature. Section III describes and summarizes the data set. Section IV presents the basic results for incoming kindergartners, demonstrating that the Black-White test score gap disappears once other confounding factors are accounted for. Section V documents the fact that a racial test-score gap emerges during the school-age years, and Section VI analyzes the reasons for this divergence. Section VII concludes.

\title{
II. Background and Previous Literature
}

The Coleman Report (Coleman et. al. 1966) was the first national study to describe ethnic

\begin{abstract}
to school with Blacks have baseline test scores upon entering kindergarten that are similar to those who are in all-White classes (Humphreys, 1988, documents a similar finding among high school students). When we eliminate from the sample Whites who have no Black children in their class (more than 60 percent of all White children fall into this category), we obtain similar results.
\end{abstract}


differences in academic achievement among children at various stages of schooling. It documented that substantial differences in educational achievement between blacks and whites not only existed at every grade level, but increased with student age. Since then, substantial effort has been devoted to understanding what variables account for the gap, as well as how and why the magnitude of the gap has changed over time. ${ }^{6}$ A number of stylized facts have emerged. Socio-economic status and the effects of poverty are important factors in explaining racial differences in educational achievement (Brooks-Gunn and Duncan 1997, Mayer 1997, BrooksGunn et. al $(1994,1995,2000)$. Even after controlling for socio-economic status in conventional regression analysis, a substantial gap still remains. That gap has generally been declining over time, although for high school students today, the gap is slightly larger than it was in the late 1980's (Grissmer et. al. 1998, Hedges and Nowell 1998, and Humphreys 1998). Finally, the gap in test scores between Blacks and Whites historically emerges before children enter kindergarten and tends to widen over time (Phillips et. al. 1998, Carneiro, Heckman, and Manoli 2002).

\section{The Data}

The Early Childhood Longitudinal Study Kindergarten Cohort (ECLS-K) is a nationally representative sample of over 20,000 children entering kindergarten in 1998. Thus far, information on these children has been gathered at four separate points in time. The full sample

${ }^{6}$ In particular, Hernstein and Murray's controversial book, The Bell Curve, published in 1994, ignited interest in the subject by arguing that genetic differences are the primary explanation for the differences between Blacks and Whites in achievement test scores. For excellent summaries of the book, see Heckman (1995) and Goldberg and Manski (1995). Examples of the discussion that emerged include Devlin et. al. (1998), Fraser (1995), and Kincheloe et. al. (1997). 
was interviewed in the fall and spring of kindergarten and spring of first grade. One-fourth of the respondents were also interviewed in the fall of first grade. The sample will eventually be followed through fifth grade. ${ }^{7}$ Roughly 1,000 schools are included in the sample, with an average of more than twenty children per school in the study. As a consequence, it is possible to conduct within-school analyses.

A wide range of data is gathered on the children in the study, which is described in detail at the ECLS website http://nces.ed.gov/ecls. We utilize just a small subset of the available information in our baseline specifications (although we also show that similar results are obtained in a much more fully specified model). Students who are missing data on test-scores, race, or age are dropped from our sample.

Summary statistics for the variables we use in our core specifications are displayed by race in Table 1, with White referring solely to non-Hispanic Whites. ${ }^{8}$ Our primary outcome variables are math and reading standardized test scores. ${ }^{9}$ Standardized tests were administered to

${ }^{7}$ In addition, there is an ECLS birth cohort that tracks a nationally representative sample of over 15,000 children born in 2001 through the first grade.

${ }^{8}$ There are also a small number of children in the data whose racial status is classified as "other." These include Hawaiian, mixed race, and Native American students. Such students are included in our regressions, but not shown in the summary statistics table.

9 These tests were developed especially for the ECLS, but are based on existing instruments including Children's Cognitive Battery (CCB); Peabody Individual Achievement Test-Revised (PIAT-R); Peabody Picture Vocabulary Test-3 (PPVT-3); Primary Test of Cognitive Skills (PTCS); and Woodcock-Johnson Psycho-Educational Battery-Revised (WJ-R).

A "general knowledge" exam was also administered. The general knowledge test is designed to capture "children's knowledge and understanding of the social, physical, and natural world and their ability to draw inferences and comprehend implications." No further information is available on the precise content of the general knowledge exam questions or skills tested. We limit the analysis to math and reading scores, primarily because of the comparability of these test scores to past research in the area. In addition, there appear to be some peculiarities in the results of the general knowledge exam. For instance, Asians score well above other 
the full sample in the fall of kindergarten and in the spring of first grade. ${ }^{10}$ The reading test includes questions designed to measure basic skills (print familiarity, letter recognition, beginning and ending sounds, rhyming sounds, and word recognition), vocabulary and comprehension, listening and reading comprehension, knowledge of the alphabet, phonetics, etc. The math test evaluates number recognition, counting, comparing and ordering numbers, solving word problems, and interpreting picture graphs. The values reported in the table are item response theory (IRT) scores provided in ECLS-K, which we have transformed to have mean zero and a standard deviation of one for the overall sample on each of the tests and time periods. ${ }^{11}$ In all instances sample weights provided in ECLS-K are used. ${ }^{12}$ White students on average score .274 standard deviations above the mean on the math exam in the fall of kindergarten, whereas Black students perform .364 standard deviations below the mean on that

groups on math and reading, but do extremely poorly on the general knowledge exam. Also, Black students do extremely poorly on the general knowledge exam, even though teachers rate them only slightly behind Whites in this area on the subjective teacher evaluations. Most of our results also appear in the general knowledge scores, and we note the instances where differences arise.

10 The tests were also given in the spring of kindergarten, but we limit our focus to the endpoints of the available data. The kindergarten spring test results are in all cases consistent with the results presented in the paper.

11 Because children were asked different questions depending on the answers they provided to the initial questions on the test, IRT-adjusted scores are preferable to simple testscore measures reflecting the number of correct answers a child provided. For more detail on the process used to generate the IRT scores, see chapter 3 of the ECLS-K Users Guide.

Our results are not sensitive to normalizing the IRT scores to have a zero mean and standard deviation equal to one.

12 Because of the complex manner in which the ECLS-K sample is drawn, different weights are suggested by the providers of the data depending upon the set of variables used. We utilize the weights recommended for making longitudinal comparisons. None of our findings are sensitive to other choices of weights, or not weighting at all. 
test, yielding a Black-White gap of .638 standard deviations. By the spring of first grade, that gap has increased to .728 standard deviations. The initial Black-White gap on reading is smaller (.401 standard deviations). Like math, however, the reading gap widens substantially to .529 standard deviations by the end of first grade. It is worth noting that the Black-White gaps are substantially smaller than those observed in earlier data sets for children of the same age. For instance, Phillips, et. al. (1998) report a raw Black-White test score gap of over one standard deviation in reading using the Children of the NLSY (CNLSY) and Infant Health and Development Program (IHDP) data sets, which covers the cohorts born in the years 1980-1987 (CNLSY) and 1984-1985 (IHDP).

A second outcome measure that we analyze is subjective teacher assessments of a child's math and reading achievement. Teachers were asked to answer 20 questions about the child's academic performance, ranking them on a scale of "Not Yet" to "Proficient." These answers were then transformed into IRT scores. As was done with test scores, these subjective assessments have been re-normalized to have mean zero and a standard deviation of one. The patterns in the teacher assessments mirror those in the test-score data: Black and Hispanic students start out substantially below Whites, and Black students lose ground over the first two years of school, whereas Hispanics maintain their position relative to Whites. The most notable difference between the test scores and teacher assessments is that Asian students are rated at or below the level of White students in the fall of kindergarten on the teacher assessments, but then gain relative to Whites over time.

The remainder of Table 1 presents summary statistics for the other variables used in the analysis. In contrast to the test score variables, for which we have observations at multiple 
points in time, most of the control variables are either collected only once (typically kindergarten fall, but in some cases kindergarten spring), or exhibit little variation over time for individual students. The most important of these covariates is a composite measure of socio-economic status constructed by the researchers conducting the ECLS survey. The components used in the SES measure are parental education, parental occupational status, and household income. Other variables included as controls are gender, child's age at the time of enrollment in kindergarten, WIC participation (a nutrition program aimed at relatively low income mothers and children), mother's age at first birth, birth weight, and the number of children's books in the home. ${ }^{13}$ There are substantial differences across races on many of these variables. Black children in the sample are growing up under circumstances likely to be less conducive to academic achievement than White children: lower socio-economic status, fewer children's books in the home, etc. Hispanics are also worse off than Whites on average. For Asians, the patterns are more mixed. While this may seem an odd set of covariates to include, our rationale is that the results we obtain with this small set of variables mirrors the findings when we include an exhaustive set of over 100 controls. ${ }^{14}$ We caution against a causal interpretation of the coefficients on the covariates, which we view as proxies for a broad set of environmental and behavioral factors. In light of past research that has had great difficulty making the Black-White test score gap disappear, we focus on the results from these very sparse regressions to highlight the fact that the sharp differences between our results and earlier studies is not primarily a consequence of the availability of better covariates in the ECLS.

\footnotetext{
${ }^{13} \mathrm{~A}$ more detailed description of each of the variables used is provided in the appendix.

${ }^{14}$ We also present the results using a fuller set of controls for completeness.
} 
IV. Estimating racial test score gaps for incoming kindergartners

Table 2 presents a series of estimates of the racial test score gap for the tests taken in the fall of kindergarten. The specifications estimated are of the form

$\operatorname{TESTSCORE}_{i}=\operatorname{RACE}_{i}{ }^{\prime}+X_{i}{ }^{\prime} 1+{ }_{i}$

where $i$ indexes students. A full set of race dummies are included in the regression, with White as the omitted category. Consequently, the coefficients on race capture the gap between the named racial category and Whites. Our primary emphasis, is on the Black-White test score gap. The vector of other covariates included in the specification, denoted $X_{i}$, varies across columns in Table 2. As one moves to the right in the table, the set of covariates steadily grows. In all instances, the estimation is done using weighted least squares, with weights corresponding to the sampling weights provided in the data set.

The first and sixth columns of Table 2 presents the differences in means, not including any covariates. These results simply reflect the raw test score gaps reported in Table 1 . The next specification adds the composite indicator of socio-economic status constructed by the ECLS survey administrators. Socio-economic status is an important predictor of incoming test scores, carrying a t-statistic over forty. A one-standard deviation increase in the SES variable is associated with a .41 increase in both math and reading test scores. Controlling for socioeconomic status substantially reduces the estimated racial gaps in test scores (see also Coley 2002). The Black-White gap in math falls by more than forty percent; the reading gap is reduced by more than two-thirds. The changes in the other race coefficients are not as large, but in every 
instance the estimated gaps shrink, and R-squared increases substantially.

The next set of specifications adds the number of children's books in the child's home, the square of that variable, and an indicator variable equal to one if the number of books takes on a missing value for that student. The number of books is strongly positively associated with high kindergarten test scores on both math and reading. ${ }^{15}$ Evaluated at the mean, a one-standard deviation increase in the number of books (from 72 to 137) is associated with an increase of .143 (.115) in math and reading respectively. This variable seems to serve as a useful proxy for capturing the conduciveness of the home environment to academic success. Including number of books reduces the Black-White gap on math to less than one-fourth of a standard deviation and completely eliminates the gap in reading. The gap for Hispanics also shrinks. The Asian-White gap, however, becomes even larger than the raw gap when number of books is added to the regression.

Columns 4 and 9 add controls for gender, age, birth weight, indicator variables for having a mother whose first birth came when she was a teenager or over 30 (the omitted category is having a first birth in one's twenties), and WIC participation. These covariates generally enter with the expected sign. Older children, those with higher birth weights, those with older mother's at the time of first birth all score better. Children on WIC do worse on the tests, suggesting that this variable is not capturing any real benefits the program might provide, but rather, the fact that eligibility for WIC is a proxy for growing up poor that the SES variable is not adequately capturing. Adding these variables to the specification further improves the test scores

15 The marginal benefit associated with one additional book decreases as more books are added. Beyond roughly 150 books, the marginal impact turns negative. Only 16 percent of the sample lies above this cutoff point. 
of Blacks and Hispanics. In fact, the estimates suggest that, controlling for other factors, Black children actually score slightly better than Whites in reading, and only slightly worse in math. Only a small gap persists for Hispanics. The advantage enjoyed by Asians becomes even greater. R-squared increases substantially relative to the previous specification.

The fact that the Black-White test score gap essentially disappears with the inclusion of sufficient controls in Table 2 is a very striking result, given that in past research a substantial gap has persisted, regardless of the covariates included. ${ }^{16}$ For example, Hernstein and Murray (1994) reduce the gap by one-third, Neal and Johnson (1996) reduce the gap by sixty percent, and Phillips et. al., (1998) reduce the black-white gap by two thirds. ${ }^{17}$ Indeed, despite the fact that Phillips et. al. (1998) have the greatest success in explaining the racial differences in reading achievement, the residual gap is almost as large as the raw gap in our data. There is little reason to believe that it is the precise set of covariates available in the ECLS that accounts for our ability to eliminate the gap. For example, just accounting for socio-economic status at kindergarten entry, we estimate the Black-White gap in reading as -.134 compared to -.67 in Phillips et. al. (1998). Rather, it appears either that the Blacks we examine made real gains

${ }^{16}$ On the test of general knowledge, the Black-White gap does not fully disappear. Black students test almost one-full standard deviation behind Whites in a raw comparison of means. That gap falls to .3 when controls are included. On the subjective teacher assessments, the raw gap in general knowledge between Blacks and Whites is much smaller (.25 standard deviations) and does shrink almost to zero with the inclusion of controls.

${ }^{17}$ The two exceptions we are aware of in which the Black-White test score gap has been made to disappear are Li and Poirier (2002) and Carneiro, Heckman, and Manoli (2002). Li and Poirier (2002), using a Bayesian structural model, find no systematic differences between Blacks and Whites using the NLSY. Hernstein and Murray (1994) and Phillips et. al., (1998), using different methods on the same data, find large gaps still persists. Using Children of the NLSY, Carneiro, Heckman, and Manoli (2002) find that on some tests, racial gaps disappear with controls, although large gaps remain on other tests designed to capture similar sets of skills. 
relative to Whites, or alternatively, non-random selection into earlier data sets led to exaggerated estimates of the racial gap in earlier studies. ${ }^{18}$

The final specifications in Table 2 (columns 5 and 10) include an exhaustive set of roughly100 covariates capturing city size, neighborhood characteristics, region of the country, parental education, parental income, parental occupational status, family size and structure, whether the mother worked, type of pre-school program participation, whether English is spoken at home, and the extent of parental involvement in a child's life and school. We report only a subset of the covariates in Table 2; full results are presented in Appendix Table 1. Almost all of the controls enter in the predicted direction and with coefficients of plausible magnitude. Interestingly, none of the coefficients on race change appreciably. Only a few of the parameters on the controls included in the parsimonious specifications are greatly affected either, and these are easily explained. The socio-economic status coefficient shrinks because the full set of covariates includes variables that go into the construction of the composite indicator such as parent's income and occupational status. The coefficient on age becomes highly negative because an age squared term (which is positive and significant) is included in the full specification. The inclusion of these additional variables does little to improve the fit of the model.

Table 3 explores the sensitivity of the estimated racial gaps in test scores across a wide variety of alternative specifications and sub-samples of the data. We report only the race

${ }^{18}$ When we limit our data set to groups that previous data sets over-sampled (low birthweight babies in the case of IHDP or children born to teen mothers in CNLSY), however, our results are virtually unchanged, adding credence to the argument that Blacks have made real gains. 
coefficients and associated standard errors in the table. The top row of the table presents the baseline results using a full sample and our parsimonious set of controls (corresponding to columns 4 and 9 of Table 2). Weighting all of the observations equally in the regressions leaves the Black-White gap in math and reading remain virtually unchanged. Employing an alternative test-score measure (T-scores, which are norm-referenced measurements of achievement) has very little impact on the results.

One might be concerned that restricting all the coefficient estimates to be identical across the entire sample may yield misleading results. Regressions on a common support (e.g. only on single mothers, or only in rural areas) provide one means of addressing this concern. Almost every subset of the data examined yields results roughly similar to those for the overall sample. There is some slight evidence that Black females do better relative to Whites than do Black males. The results appear to be quite consistent across quintiles of the socio-economic status distribution. Due in part to relatively imprecise estimates, the equality of Black and White test scores on math and reading tests can rarely be rejected for any of the quintiles. Rural Blacks do somewhat worse relative to whites than those in central cities. Blacks in private schools appear to do especially well, consistent with Neal (1997) and Grogger and Neal (2000). ${ }^{19}$

The results presented in Tables 2 and 3 maintain the assumption that children of different races are equally responsive to changes in covariates. Cross-race differences in coefficients are

${ }^{19}$ We have also experimented with limiting the sample to the set of children for whom there is substantial overlap across races in background characteristics. More specifically, we ran probits with an indicator variable for Black as the dependent variable and the full set of covariates as predictors. When we drop from the sample the roughly 30 percent of students whose predicted probability of being Black is less than 10 percent or greater than 90 percent, the Black-White gap on math rises slightly and the reading gap becomes closer to zero. 
potentially important because they affect the interpretation of the racial test score gap estimates in the preceding tables. Black children experience worse environments on average. If Black children do not derive as much benefit from improvements in socio-economic status, number of children's books, higher birth weight, etc., then our earlier results will overstate the convergence in Black-White test scores.

Table 4 presents within-race estimates of our basic specifications to determine how large this bias may be. Columns 1 and 6 replicate the coefficient estimates from the full sample. The remaining columns present results within a specific race category. The Black children in our sample are less responsive to changes in socio-economic status than Whites: a one-standard deviation improvement in socio-economic status for a Black child is associated with a .176 standard deviation increase in math scores, compared to .316 for a White child. For most of the other covariates, however, the White and Black coefficients are similar. Using the coefficients in columns 3 and 8 , a Black child that had the characteristics of the average White child in the sample would be estimated to score -.21 standard deviations below that White child on math and be almost exactly even in reading. ${ }^{20}$ Thus, to the extent that public policies are designed to improve the environments experienced by Black children, our baseline estimates may slightly overstate the ground that would be gained by Blacks. This logic also holds for Hispanics, but not for Asians, who seem to be more responsive to environmental influences.

20 Using the coefficients in columns 2 and 7, a White student that had the characteristics of the average Black child would be expected to score .07 (.13) standard deviations above (below) that average Black child on math (reading) respectively. These results are almost identical to the predictions from our baseline specification, because the coefficients from the White regression are quite similar to those from the full sample. 
$\mathrm{V}$. The evolution of the racial test score gaps as children age

The results of the previous section demonstrate that although Black test scores lag Whites by a large margin, the inclusion of a small number of covariates eliminates any systematic differences in the math and reading performances of Whites and Blacks entering kindergarten. Hispanics somewhat lag Whites, and Asians exceed all of the other races. In this section, we explore how those racial gaps change over time.

In terms of raw test scores, simple calculations based on the numbers in Table 1 show that Black students lose some ground relative to Whites between the fall of kindergarten and the spring of first grade: .090 standard deviations on math and .128 standard deviations on reading. Table 5 presents regression results for those two time periods We report results only from our "parsimonious" regression specification; similar racial gaps emerge when the exhaustive set of covariates is included. Controlling for other factors in the regressions, Black students appear to lose much more ground than they do in the raw means: -.156 standard deviations on math and .188 standard deviations on reading. ${ }^{21}$ If Black students in the sample continue to lose ground through ninth grade at the rate experienced in the first two years of school, they will lag White students on average by a full standard deviation in raw math and reading scores and over twothirds of a standard deviation in math even after controlling for observable characteristics (substantially smaller for reading). Raw gaps of that magnitude would be similar to those found in previous studies of high-school age children (Grissmer, Flanagan, and Williamson 1998,

\footnotetext{
${ }^{21}$ Similar results (not shown in the table) are obtained when we include the full set of nearly 100 covariates. In those specifications, Black students lose .136 standard deviations on math and .109 standard deviations on reading. Including the fall kindergarten test score as a covariate predicting the spring first grade test score also has little impact on the results: Black students lose .192 (.140) standard deviations in math (reading).
} 
Hedges and Nowell 1998, Humphreys 1988, Phillips et. al., 1998, and Phillips, 2000).

In striking contrast to the Black-White gap, Hispanics show gains relative to Whites between the beginning of kindergarten and the end of first grade. Asians lose roughly as much ground as Blacks on math (although they start ahead of Whites) and also fall slightly on reading. Thus, Black students are not only losing ground relative to Whites, but even more so relative to Hispanics, and somewhat less compared to Asians.

VI. Why are Black students losing ground in the first two years of school?

Understanding why Black students fare worse in the first two years of school, is a question of paramount importance for two reasons. First, knowing the source of the divergence may aid in developing public policies to alleviate the problem. Second, determining the explanation for the widening gap will help to determine whether the simple linear extrapolation over the academic career is a plausible conjecture.

There are a number of plausible explanations as to why the racial gap in test scores grows as children age: (1) Black children attend lower quality schools on average, (2) the importance of parental/environmental contributions may grow over time. Since Black children are on average disadvantaged in this regard, they fall behind, (3) because of worse home and neighborhood environments, Black students suffer worse "summer setbacks" when school is not in session, (4) the results are an artifact of the particular standardized tests used/poor measurement of a child's environment, rather than representing true losses, (5) something about the interaction between Black students and schools interferes with the learning process. Such factors might include discrimination/low expectations on the part of teachers toward Black students, systematic 
differences in self-control or socialization across children of different races, etc., or (6) the fall kindergarten test scores are measuring a different set of skills than the later tests and the gap between Whites and Blacks is greater on the set of skills measured later. We address each of these hypotheses in turn.

Are Black students losing ground because they attend worse schools?

There is substantial racial segregation in school attendance in the United States. In our data which samples roughly 20 children each from approximately 1,000 schools, in 35 percent of those schools there is not a single Black child in the sample. ${ }^{22}$ The mean Black student in our sample attends a school that is 59 percent Black and 8 percent Hispanic. In contrast, the typical White student goes to a school that is only 6 percent Black and 5 percent Hispanic. Given that the overlap in schools attended by Blacks and Whites is relatively limited, one plausible explanation for why Black students are losing ground is that they attend worse schools on average.

Because our data set has many individuals from each school include in the sampling frame, school-fixed effects can be included in the estimation. With school-fixed effects, the estimated Black-White test score gap is identified off of the relative performance of Blacks and Whites attending the same school, as opposed to across schools. To the extent that differential average school quality across races is the complete explanation for the widening racial test score gap, one would predict that the gap should not widen over time when comparing Blacks and Whites attending the same school. There are, of course, thorny issues of sample selection that potentially complicate the interpretation of these results: White students who elect to attend

\footnotetext{
${ }^{22}$ Black students may attend these schools, but just not be in the classrooms sampled.
} 
schools with Black students may have differential test score trajectories than other White students, even if they had gone to all White schools. Nonetheless, looking within schools provides a first attempt at testing this hypothesis.

The comparison of changes in the Black-White test score gap over time including and excluding school-fixed effects is presented in Table 6. All of the specifications in the table include the parsimonious set of covariates, although only the coefficient on the Black-White gap is shown in the table. The first three columns reflect the full sample of students. The remaining columns restrict the sample to schools that have both Black and White children in our sample. This set of students is relevant because only mixed-race schools provide useful variation to identify the racial test score gap when school-fixed effects are included.

Column 3 of the table shows the baseline results reflecting the fact that Blacks are losing ground in the full sample (-.156 standard deviations relative to Whites in math, -.188 standard deviations in reading). When we eliminate students attending all-White schools from the sample, but otherwise estimate identical specifications, the results are not greatly affected. Blacks continue to lose substantial ground by the end of first grade. When school-fixed effects are included in the regression (columns 7-9), the Black-White test-score gap is identified off of differences between Blacks and Whites attending the same school. The estimates of ground lost by Blacks shrinks to less than one-third of the magnitude in the full sample, and is not statistically different from zero in these specifications. $^{23}$

23 This finding in some ways parallels Currie and Thomas's (1995) finding that students early gains for students who attend Head Start tend to disappear due to low quality schools that these students later attend. In our data, however, there is no positive effect of Head Start on student test scores even in kindergarten, once other factors are controlled for. 
These findings are consistent with - but not definitive proof of - the argument that systematic differences in school quality for Blacks and Whites may explain the divergence in test scores. An alternative explanation is that Whites who choose to attend schools with Blacks are systematically worse than other Whites. Note, however, that a comparison of columns 1 and 4 show that in the fall of kindergarten Black students actually fare somewhat worse relative to Whites who attend schools with Blacks then they do with the full sample of Whites. This finding suggests that the Whites who go to school with Blacks (controlling for observables) actually achieve at a slightly higher level than do those who attend all-White schools, which is consistent with previous research. Moreover, comparing columns 4 and 7, in kindergarten fall, Blacks do even worse relative to Whites attending the same school than they do compared to other Whites. Thus, a simple selection story in which low-achieving Whites are more likely to go to school with Blacks is not consistent with the data. On the other hand, we cannot rule out a priori the possibility that Whites who attend school with Blacks are on lower academic trajectories, despite the fact that they initially score better on tests than other Whites.

If Blacks attend worse schools than Whites on average, one might expect that this would be reflected in observable characteristics of the schools. Table 7 analyzes this issue. Each row of the table corresponds to a different measure of school quality. Column 1 presents means and standard deviations of each variable in the data. Columns 2-5 report the race coefficients from regressions that are parallel to those elsewhere in the paper, except that school inputs are the dependent variable rather than test scores. Thus, the entries in columns 2-5 reflect the extent to which children of other races attend higher or lower quality schools on each of the measures, controlling for our "parsimonious" set of covariates. On traditional measures of school quality 
such as class size, teacher's education, computers in class, and internet connections, differences between blacks and whites are small. On the other hand, the percentage of students eligible for free lunch, the degree of gang problems in school, the amount of loitering in front of the school by non-students, and the amount of litter around the schools are much higher for blacks.

There are a number of important weaknesses in the argument that differential school quality explains the divergent trajectories of Whites and Blacks. First, the observable measures of school inputs included in Table 7 explain only a small fraction of the variation in student outcomes. For instance, adding the school input measures to our basic student-level test-score regressions only increases the R-squared of the regression by .05. Second, even after the school input measures are added to the test-score regressions, the gap between Blacks and Whites continues to widen. Thus, these particular school inputs are not adequately capturing the critical differences across schools. Finally, on the measured school inputs, both Hispanics and Asians also experience worse schools than Whites, but neither of those groups is losing ground. Because of these important weaknesses in the story, the evidence linking school quality differences to the poor trajectories of Blacks can be characterized as no more than suggestive.

\section{Does the importance of parental/environmental inputs grow as children age?}

Black children tend to grow up in environments less conducive to high educational attainment. If the importance of parental/environmental inputs grows as children age, Black students would be expected to lose ground relative to Whites. The evidence in Table 5, however, argues just the opposite. If that were true, than one would expect to observe the raw gaps widening between Blacks and Whites, but to the extent our control variables adequately capture a child's environment, the residual gap after including all the covariates would remain 
constant. In fact, however, the residual gap increases more than the raw gap contradicting this explanation. $^{24}$ Also, the magnitude of the coefficients on socio-economic status, age at kindergarten entry, and mother's age at first birth are smaller in the first-grade test-score regressions. That suggests that the relative importance of non-school factors decreases over time, presumably because schools become a critical input into educational gains once children enter school. $^{25}$

Do Black children suffer worse summer setbacks when school is not in session?

Entwisle and Alexander (1992 and 1994) and Heyns (1978), have argued that Black students lose more ground over the summer than White students as a consequence of worse home and neighborhood environments, and they gain ground over the school year while in school. If this were the explanation for the falling performance of Blacks, then public policies should be aimed not at schools, but rather, summer interventions. Our data provides a unique opportunity to test this hypothesis because a subset of the sample is tested both in the spring of kindergarten and in the fall of first grade, shortly after students return to class, allowing us to isolate the relative summer setbacks for Blacks and Whites. The results are reported in Table 8.

${ }^{24}$ Indeed, from a theoretical perspective, one might expect that the opposite hypothesis would hold true: the importance of parental inputs declines with age. Prior to reaching school age, the relative share of educational inputs provided by parents is very large. Once school starts, much of the burden for educating is shifted to the schools. Our empirical evidence does not, however, provide much support for this conjecture either.

25 An alternative explanation for the shrinking coefficient on the SES variable is that socio-economic status varies over time. Therefore, using the kindergarten value of the SES variable in the first grade regression induces measurement error. That explanation cannot explain the declining coefficients on age at school entry and mother's age at birth. Moreover, for other variables that are time varying, like number of books and WIC participation, the coefficients do not shrink in the first-grade regression. 
For the subset of the sample that is tested in the fall of first grade (about one-fourth of the students), we report at each point in time both the raw test score gap and the residual gap controlling for our parsimonious set of covariates. For the regression results, only the coefficient reflecting the Black-White test score gap is shown in the table, and each entry in the table is from a separate regression. The test score gaps in the fall of kindergarten (column 1) and spring of first grade (column 4) for this subset of the sample are similar to those for the sample as a whole, suggesting that the sub-sample is representative. Of greater interest is a comparison of the test scores in the spring of kindergarten versus the fall of first grade, since most of the intervening time was spent outside of school. On the raw scores, there is little difference before and after the summer break; to the extent there is any gap, it favors Black students. With controls, Black students lose slightly relative to whites over the summer on math (the gap rises from -.097 to -.134$)$, but the null hypothesis of no change cannot be rejected. The point estimates for reading show slight gains by Black students relative to Whites over the summer. Thus, the empirical results lend little support to the hypothesis that differential summer setbacks explain the lost ground of Black students in our sample. We do observe Blacks losing ground during the school year in both subjects in both years, in direct conflict with Entwisle and Alexander (1992).

Are the results simply an artifact of standardized testing?

Given the potential difficulties of evaluating student achievement using standardized tests in children so young, one possibility is that our results are simply an artifact of standardized testing. To assess this hypothesis, we examined the relative performance of children of different races on subject teacher evaluations. The teacher assessments were normalized to be mean zero 
with a standard deviation equal to one. The regressions are identical to the specifications using test scores with one important difference. Because of concerns about heterogeneity across teachers in the way they may rate students on these subjective evaluations, we include teacherfixed effects in all of the regressions using these measures. Thus, the estimates are based on a student's evaluation relative to other students in the same classroom.

The results for teacher assessments are presented in Table 9. The odd columns contain the raw gaps across races on the assessments; the even columns control for our parsimonious set of regressors. As before, the interpretation of the coefficients is standard deviation units. In kindergarten fall, Black students are judged by teachers to be .26 to .28 standard deviations behind Whites on both math and reading. These gaps are smaller than those observed on the standardized tests. Controlling for other characteristics, the Black-White gap shrinks to .103 standard deviations on math and .066 standard deviations on reading. Just as was the case with test scores, the gap between Whites and Blacks widens substantially by the end of first grade. Thus, the patterns in the test scores are replicated in teacher assessments. This is true not only for Blacks, but also for Hispanics and Asians. The most notable divergence in results between test scores and teacher assessments is that teachers initially rate Asians as performing no better than Whites, but increase their evaluation of Asians over time. In the test score data, the opposite pattern emerges.

Can teacher bias or differential socialization explain Black students losing ground?

If, as some have argued, White teachers have lower expectations for Black children or otherwise discriminate against them in the classroom (Baron, Tom, and Cooper 1985, Dusek, 1975, Ferguson 1998, and Lightfoot 1978), then one would predict that Black students with 
White teachers should lose more ground than Black students with Black teachers. Table 10 tests this theory. Columns 1 and 2 correspond to the sub-sample of students neither of whose teachers in kindergarten or first grade are Black. Columns 3 and 4 reflect students who have at least one Black teacher. Note that less than five percent of White students have a Black teacher by the end of first grade, compared to over fifty percent of Black students. The top rows of the table report test scores without teacher-fixed effects, the middle panel reports test scores including teacherfixed effects, and the bottom panel reports subjective teacher assessments (with teacher-fixed effects). The results are generally similar across the three sets of analysis. Black children who have at least one Black teacher start out somewhat worse relative to their White peers on math and slightly better on reading, relative to Black students who have two Black teachers. By the end of first grade, however, the Black-White test score gap is greater across the board for students who have at least one Black teacher (i.e., the coefficients in column 4 are always more negative than those in column 2). This finding is exactly the opposite of what one would predict from a discrimination story.

Although not shown in tabular form, we have also explored whether differences in socialization and behavior might explain the results. The data set includes a number of variables that might be correlated with cultural differences in socialization. Parents and teachers were asked to rate the child on various social skills including: self control, approaches to learning, interpersonal skills, and exhibiting problem behaviors. The inclusion of these variables in our regressions, however, had virtually no impact on the measured Black-White test score gap 
or it's trajectory over time. ${ }^{26}$

Does the material tested change as children age in a manner that lowers the relative performance of Black students?

In personal correspondence, ECLS reports that the fraction of the exam devoted to each set of skills remains constant as children age. In the fall of kindergarten, few children are expected to correctly answer questions involving multiplication and division, and by the spring of first grade, few children are expected to miss questions involving counting. Nonetheless, the same mix of questions is asked.

Still, it is potentially interesting to compare the relative performance of Black and White children on the different types of questions over time. Table 11 reports the Black-White gap on questions assessing specific sets of skills at both the beginning and the end of the sample. The estimates in the table are based on specifications including our parsimonious set of regressors, and the magnitude of the estimates is once again interpretable as standard deviation units. In math, the lost ground on the part of Blacks is attributable almost solely to poor performance on addition, subtraction, multiplication and division. Black students perform almost as well as Whites in the fall of kindergarten on these tasks, but lag Whites by over two-tenths of a standard deviation by the spring of first grade. To the extent that skill in manipulating numbers is likely to be a more important input into understanding higher-order math than are simple tasks such as counting or evaluating relative size, these results may foreshadow continued losses for Blacks relative to Whites in math as they age. Blacks lose roughly equal ground on all aspects of

${ }^{26}$ Although we do not directly test other social theoretic explanations such as "stereotype threat" and "acting white," it would seem unlikely that they would affect children at such an early age. 
reading proficiency.

\section{Conclusion}

Previous efforts to explain the Black-White test score gap have generally fallen short - a substantial residual remained for Black students, even after controlling for a full set of available covariates. Using a new data set, we demonstrate that among entering kindergartners, the BlackWhite gap in test scores can be essentially eliminated by controlling for just a small number of observable characteristics of the children and their environment. Once students enter school, the gap between White and Black children grows, even conditional on observable factors. We test a number of possible explanations for why Blacks lose ground. The only hypothesis which receives any support is that Black students attend worse schools on average.

Compared to previous studies, our results provide reason for optimism. Research on earlier cohorts of children found much greater Black-White test score gaps, both in the raw scores and controlling for observables. When we attempt to mimic the non-random sample frames in earlier research (for example only looking at low-birth weight babies as in IHDP), we continue to find much smaller gaps in our sample. One plausible explanation for the differences between the current sample and cohorts attending kindergarten 10-30 years ago is that the current cohort of Blacks has made real gains relative to Whites. Reconciling our results with past studies represents an important direction for future research. 
Table 1: Summary Statistics by Race: Student Characteristics

\begin{tabular}{|c|c|c|c|c|c|}
\hline Variable & $\begin{array}{l}\text { Full } \\
\text { sample }\end{array}$ & White & Black & Hispanic & Asian \\
\hline \multicolumn{6}{|l|}{ Test scores } \\
\hline Fall kindergarten math & $\begin{array}{l}.026 \\
(1.038)\end{array}$ & $\begin{array}{c}.274 \\
(1.073)\end{array}$ & $\begin{array}{l}-.364 \\
(.765)\end{array}$ & $\begin{array}{l}-.448 \\
(.898)\end{array}$ & $\begin{array}{c}.424 \\
(1.275)\end{array}$ \\
\hline Spring first grade math & $\begin{array}{c}.013 \\
(1.092)\end{array}$ & $.249(.984)$ & $\begin{array}{l}-.479 \\
(.977)\end{array}$ & $\begin{array}{l}-.314 \\
(1.040)\end{array}$ & $\begin{array}{c}.272 \\
(1.089)\end{array}$ \\
\hline Fall kindergarten reading & $\begin{array}{c}.014 \\
(1.010)\end{array}$ & $\begin{array}{l}.147 \\
(1.073)\end{array}$ & $\begin{array}{l}-.255 \\
(.892)\end{array}$ & $\begin{array}{l}-.280 \\
(.944)\end{array}$ & $\begin{array}{l}.481 \\
(1.459)\end{array}$ \\
\hline Spring first grade reading & $\begin{array}{c}.033 \\
(1.123)\end{array}$ & $\begin{array}{c}.175 \\
(1.073)\end{array}$ & $\begin{array}{c}-.354 \\
(1.062)\end{array}$ & $\begin{array}{c}-.134 \\
(1.062)\end{array}$ & $\begin{array}{c}.472 \\
(1.088)\end{array}$ \\
\hline \multicolumn{6}{|l|}{ Subjective teacher assessments } \\
\hline Fall kindergarten math & $\begin{array}{l}.071 \\
(1.115)\end{array}$ & $\begin{array}{c}.249 \\
(1.084)\end{array}$ & $\begin{array}{l}-.178 \\
(1.001)\end{array}$ & $\begin{array}{l}-.286 \\
(.988)\end{array}$ & $\begin{array}{l}.129 \\
(1.269)\end{array}$ \\
\hline Spring first grade math & $\begin{array}{l}-.005 \\
(1.115)\end{array}$ & $\begin{array}{l}.130 \\
(1.084)\end{array}$ & $\begin{array}{l}-.355 \\
(1.101)\end{array}$ & $\begin{array}{l}-.163 \\
(1.102)\end{array}$ & $\begin{array}{l}.234 \\
(.983)\end{array}$ \\
\hline Fall kindergarten reading & $\begin{array}{c}.081 \\
(1.041)\end{array}$ & $\begin{array}{l}.267 \\
(1.050)\end{array}$ & $\begin{array}{l}-.114 \\
(1.025)\end{array}$ & $\begin{array}{l}-.354 \\
(1.043)\end{array}$ & $\begin{array}{c}.063 \\
(1.212)\end{array}$ \\
\hline Spring first grade reading & $\begin{array}{c}.006 \\
(1.145) \\
\end{array}$ & $\begin{array}{c}.118 \\
(1.050)\end{array}$ & $\begin{array}{c}-.252 \\
(1.177) \\
\end{array}$ & $\begin{array}{c}-.146 \\
(1.127)\end{array}$ & $\begin{array}{c}.206 \\
(1.095)\end{array}$ \\
\hline \multicolumn{6}{|l|}{ Race } \\
\hline White & $.578(.550)$ & 1.000 & .000 & .000 & .000 \\
\hline Black & $.161(.390)$ & .000 & 1.000 & .000 & .000 \\
\hline Hispanic & $.189(.390)$ & .000 & .000 & 1.000 & .000 \\
\hline Asian & $.028(.130)$ & .000 & .000 & .000 & 1.000 \\
\hline Other & $.045(.260)$ & .000 & .000 & .000 & .000 \\
\hline \multicolumn{6}{|l|}{ Other controls } \\
\hline Female & $.486(.520)$ & $.481(.594)$ & $.495(.536)$ & $\begin{array}{l}.494 \\
(.542)\end{array}$ & $\begin{array}{l}.503 \\
(.591)\end{array}$ \\
\hline $\begin{array}{l}\text { Age (in months), fall of } \\
\text { Kindergarten }\end{array}$ & $\begin{array}{l}67.061 \\
(4.811)\end{array}$ & $\begin{array}{l}67.402 \\
(.4 .752)\end{array}$ & $\begin{array}{l}66.877 \\
(4.776)\end{array}$ & $\begin{array}{l}66.413 \\
(4.773)\end{array}$ & $\begin{array}{l}65.927 \\
(4.639)\end{array}$ \\
\hline SES composite measure & $\begin{array}{l}-.018 \\
(.910)\end{array}$ & $.202(.792)$ & $\begin{array}{l}-.359 \\
(.780)\end{array}$ & $\begin{array}{l}-.423 \\
(.759)\end{array}$ & $\begin{array}{l}.312 \\
(1.034)\end{array}$ \\
\hline $\begin{array}{l}\text { Number of children's books } \\
\text { in the home }\end{array}$ & $\begin{array}{c}71.946 \\
(64.551)\end{array}$ & $\begin{array}{c}93.121 \\
(64.792)\end{array}$ & $\begin{array}{c}39.014 \\
(41.986)\end{array}$ & $\begin{array}{c}40.849 \\
(47.752)\end{array}$ & $\begin{array}{c}49.333 \\
(55.859)\end{array}$ \\
\hline
\end{tabular}




\begin{tabular}{|l|c|c|c|c|c|}
\hline $\begin{array}{l}\text { Mother's age at time of first } \\
\text { Birth }\end{array}$ & $\begin{array}{c}23.342 \\
(6.052)\end{array}$ & $\begin{array}{c}24.579 \\
(5.916)\end{array}$ & $\begin{array}{c}20.548 \\
(5.139)\end{array}$ & $\begin{array}{c}21.762 \\
(5.256)\end{array}$ & $\begin{array}{c}25.807 \\
(6.330)\end{array}$ \\
\hline $\begin{array}{l}\text { Child's birth weight (in } \\
\text { ounces) }\end{array}$ & $\begin{array}{c}117.827 \\
(23.847)\end{array}$ & $\begin{array}{c}120.256 \\
(22.942)\end{array}$ & $\begin{array}{c}110.315 \\
(25.373)\end{array}$ & $\begin{array}{c}117.091 \\
(23.048)\end{array}$ & $\begin{array}{c}112.667 \\
(22.498)\end{array}$ \\
\hline WIC participation & $.475(.517)$ & $.332(.493)$ & $.772(.481)$ & $\begin{array}{c}.652 \\
(.539)\end{array}$ & $\begin{array}{c}.313 \\
(.529)\end{array}$ \\
\hline Frequency of missing values & \multicolumn{1}{|l|}{} & & & \\
\hline $\begin{array}{l}\text { Missing number of children's } \\
\text { books in the home }\end{array}$ & $.010(.130)$ & $.010(.099)$ & $\begin{array}{c}.008 \\
(.097)\end{array}$ & $\begin{array}{c}.007 \\
(.108)\end{array}$ & $\begin{array}{c}.017 \\
(.148)\end{array}$ \\
\hline Missing WIC & $.012(.130)$ & $.007(.099)$ & $\begin{array}{c}.029 \\
(.195)\end{array}$ & $\begin{array}{c}.014 \\
(.108)\end{array}$ & $\begin{array}{c}.010 \\
(.118)\end{array}$ \\
\hline Missing mother's age & $.020(.130)$ & $.008(.099)$ & $\begin{array}{c}.049 \\
(.244)\end{array}$ & $\begin{array}{c}.022 \\
(.163)\end{array}$ & $\begin{array}{c}.045 \\
(.207)\end{array}$ \\
\hline Missing birth weight & $.128(.390)$ & $.100(.297)$ & $\begin{array}{c}.150 \\
(.390)\end{array}$ & $\begin{array}{c}.170 \\
(.434)\end{array}$ & $\begin{array}{c}.246 \\
(.502)\end{array}$ \\
\hline
\end{tabular}

Notes: The values in the tables are means and standard deviations of student-level data for those students in ECLS-K who do not having missing values for test scores, race, or age. Test scores are IRT scores, normalized to have a mean of zero and a standard deviation of one in the full, unweighted sample.

Subjective teacher assessments have also been normalized in this manner. The category White includes only non-Hispanic Whites. Precise definitions of the variables are provided in the data appendix. The SES composite measure incorporates information on parental education, occupational status, and family income. The SES measure ranges from -4.75 to 2.75 in the sample, with higher numbers indicating higher socio-economic status. The total number of students in the sample who receive a positive weight in the estimation is 13,290 . The bottom panel of the table reports the frequency of missing values for the covariates. In all cases, sample weights provided with ECLS are used in the calculations. 
Table 2: The Estimated Black-White Test Score Gap in Fall of Kindergarten

\begin{tabular}{|c|c|c|c|c|c|c|c|c|c|c|}
\hline \multirow[b]{2}{*}{ Variables } & \multicolumn{5}{|c|}{ Math } & \multicolumn{5}{|c|}{ Reading } \\
\hline & (1) & (2) & (3) & (4) & (5) & (6) & (7) & (8) & (9) & (10) \\
\hline Black & $\begin{array}{l}-.638 \\
(.022) \\
\end{array}$ & $\begin{array}{l}-.368 \\
(.022) \\
\end{array}$ & $\begin{array}{l}-.238 \\
(.023) \\
\end{array}$ & $\begin{array}{l}-.094 \\
(.023) \\
\end{array}$ & $\begin{array}{l}-.102 \\
(.026) \\
\end{array}$ & $\begin{array}{l}-.401 \\
(.024) \\
\end{array}$ & $\begin{array}{l}-.134 \\
(.025) \\
\end{array}$ & $\begin{array}{l}-.006 \\
(.026) \\
\end{array}$ & $\begin{array}{l}.117 \\
(.025) \\
\end{array}$ & $\begin{array}{l}.093 \\
(.030) \\
\end{array}$ \\
\hline Hispanic & $\begin{array}{l}-.722 \\
(.022)\end{array}$ & $\begin{array}{l}-.429 \\
(.023) \\
\end{array}$ & $\begin{array}{l}-.302 \\
(.024) \\
\end{array}$ & $\begin{array}{l}-.203 \\
(.022) \\
\end{array}$ & $\begin{array}{l}-.171 \\
(.028) \\
\end{array}$ & $\begin{array}{l}-.427 \\
(.027)\end{array}$ & $\begin{array}{l}-.223 \\
(.026)\end{array}$ & $\begin{array}{l}-.137 \\
(.026)\end{array}$ & $\begin{array}{l}-.064 \\
(.025)\end{array}$ & $\begin{array}{l}-.076 \\
(.029) \\
\end{array}$ \\
\hline Asian & $.150(.056)$ & $\begin{array}{l}.070 \\
(.051) \\
\end{array}$ & $\begin{array}{l}.190 \\
(.051) \\
\end{array}$ & $\begin{array}{r}.265 \\
(.048) \\
\end{array}$ & $\begin{array}{r}.274 \\
(.050) \\
\end{array}$ & $\begin{array}{l}.335 \\
(.064) \\
\end{array}$ & $\begin{array}{l}.256 \\
(.059) \\
\end{array}$ & $\begin{array}{c}.371 \\
(.059) \\
\end{array}$ & $\begin{array}{c}.409 \\
(.058) \\
\end{array}$ & $\begin{array}{l}.375 \\
(.060) \\
\end{array}$ \\
\hline Other race & $\begin{array}{l}-.503 \\
(.041) \\
\end{array}$ & $\begin{array}{l}-.329 \\
(.037) \\
\end{array}$ & $\begin{array}{l}-.253 \\
(.036) \\
\end{array}$ & $\begin{array}{l}-.158 \\
(.035) \\
\end{array}$ & $\begin{array}{l}-.113 \\
(.035) \\
\end{array}$ & $\begin{array}{l}-.401 \\
(.044) \\
\end{array}$ & $\begin{array}{l}-.230 \\
(.040) \\
\end{array}$ & $\begin{array}{l}-.155 \\
(.040) \\
\end{array}$ & $\begin{array}{l}-.072 \\
(.038) \\
\end{array}$ & $\begin{array}{l}-.014 \\
(.039) \\
\end{array}$ \\
\hline $\begin{array}{l}\text { Socio-economic status } \\
\text { composite measure }\end{array}$ & --- & $\begin{array}{l}.456 \\
(.014) \\
\end{array}$ & $\begin{array}{r}.389 \\
(.014) \\
\end{array}$ & $\begin{array}{r}.302 \\
(.014) \\
\end{array}$ & $\begin{array}{l}.072 \\
(.024) \\
\end{array}$ & --- & $\begin{array}{c}.451 \\
(.014) \\
\end{array}$ & $\begin{array}{l}.393 \\
(.015) \\
\end{array}$ & $\begin{array}{l}.299 \\
(.015) \\
\end{array}$ & $\begin{array}{c}.092 \\
(.023) \\
\end{array}$ \\
\hline Number of children's books & --- & --- & $\begin{array}{l}.007 \\
(.001) \\
\end{array}$ & $\begin{array}{r}.006 \\
(.001) \\
\end{array}$ & $\begin{array}{l}.005 \\
(.001) \\
\end{array}$ & --- & --- & $\begin{array}{l}.007 \\
(.001) \\
\end{array}$ & $\begin{array}{l}.006 \\
(.001) \\
\end{array}$ & $\begin{array}{c}.004 \\
(.001) \\
\end{array}$ \\
\hline $\begin{array}{l}(\text { Number of children's books })^{2} \\
(* 1000)\end{array}$ & --- & --- & $\begin{array}{l}-.023 \\
(.003) \\
\end{array}$ & $\begin{array}{l}-.020 \\
(.002) \\
\end{array}$ & $\begin{array}{l}-.027 \\
(.016) \\
\end{array}$ & --- & --- & $\begin{array}{l}-.025 \\
(.003) \\
\end{array}$ & $\begin{array}{l}-.021 \\
(.003) \\
\end{array}$ & $\begin{array}{l}-.017 \\
(.017) \\
\end{array}$ \\
\hline Female & --- & --- & --- & $\begin{array}{l}.010 \\
(.015) \\
\end{array}$ & $\begin{array}{l}.000 \\
(.015) \\
\end{array}$ & --- & --- & --- & $\begin{array}{l}.159 \\
(.017) \\
\end{array}$ & $\begin{array}{l}.153 \\
(.016) \\
\end{array}$ \\
\hline $\begin{array}{l}\text { Age at kindergarten fall } \\
\text { (in months) }\end{array}$ & --- & --- & --- & $\begin{array}{c}.056 \\
(.002) \\
\end{array}$ & $\begin{array}{l}-2.680 \\
(.542) \\
\end{array}$ & --- & --- & --- & $\begin{array}{c}.041 \\
(.002) \\
\end{array}$ & $\begin{array}{l}-2.409 \\
(.483) \\
\end{array}$ \\
\hline Birth weight (ounces) $(* 10)$ & --- & --- & --- & $\begin{array}{l}.029 \\
(.004) \\
\end{array}$ & $\begin{array}{l}.030 \\
(.004) \\
\end{array}$ & --- & --- & --- & $\begin{array}{c}.019 \\
(.004) \\
\end{array}$ & $\begin{array}{c}.022 \\
(.004) \\
\end{array}$ \\
\hline $\begin{array}{l}\text { Teenage mother at time of first } \\
\text { birth }\end{array}$ & --- & --- & --- & $\begin{array}{l}-.109 \\
(.018) \\
\end{array}$ & $\begin{array}{l}-.029 \\
(.021) \\
\end{array}$ & --- & --- & --- & $\begin{array}{l}-.144 \\
(.020) \\
\end{array}$ & $\begin{array}{l}-.069 \\
(.022) \\
\end{array}$ \\
\hline $\begin{array}{l}\text { Mother at least } 30 \text { at time of } \\
\text { first birth }\end{array}$ & --- & --- & --- & $\begin{array}{l}.182 \\
(.025) \\
\end{array}$ & $\begin{array}{l}.111 \\
(.028) \\
\end{array}$ & --- & --- & --- & $\begin{array}{c}.226 \\
(.027) \\
\end{array}$ & $\begin{array}{c}.155 \\
(.030) \\
\end{array}$ \\
\hline WIC Participant & --- & --- & --- & $\begin{array}{l}-.211 \\
(.019) \\
\end{array}$ & $\begin{array}{l}-.120 \\
(.020) \\
\end{array}$ & --- & --- & --- & $\begin{array}{l}-.184 \\
(.021) \\
\end{array}$ & $\begin{array}{l}-.104 \\
(.021) \\
\end{array}$ \\
\hline R-squared & 0.108 & 0.223 & 0.239 & 0.317 & 0.354 & 0.045 & 0.16 & 0.175 & 0.233 & 0.279 \\
\hline Number of observations & & & 13290 & & & & & 12601 & & \\
\hline $\begin{array}{l}\text { Full set of covariates included } \\
\text { in regression? }\end{array}$ & $\mathrm{N}$ & $\mathrm{N}$ & $\mathrm{N}$ & $\mathrm{N}$ & $\mathrm{Y}$ & $\mathrm{N}$ & $\mathrm{N}$ & $\mathrm{N}$ & $\mathrm{N}$ & $\mathrm{Y}$ \\
\hline
\end{tabular}


Notes: The Dependent variable is the math or reading test score in the fall of kindergarten. Test scores are IRT scores, normalized to have a mean of zero and a standard deviation of one in the full, unweighted sample. Non-Hispanic Whites are the omitted race category, so all of the race coefficients are gaps relative to that group. The unit of observation is a student. Standard errors in parentheses. Estimation is done using weighted least squares, using sample weights provided in the data set. In addition to the variables included in the table, indicator variables for students with missing values on each covariate are also included in the regressions. In addition, columns 5 and 10 report only a subset of the coefficients from regressions with 98 covariates included in the specification. The full results for columns 5 and 10 are reported in appendix table A-1. Note that the specifications in columns 5 and 10 include age and age squared; that is why the coefficient on age changes so dramatically relative to other columns in the table. 
Table 3: Sensitivity Analysis/Extensions of the Basic Model for Fall Kindergarten Test Scores

\begin{tabular}{|c|c|c|c|c|c|c|}
\hline \multirow{2}{*}{ Specification } & \multicolumn{2}{|c|}{ Coefficient on Black for: } & \multicolumn{2}{|c|}{ Coefficient on Hispanic for: } & \multicolumn{2}{|c|}{ Coefficient on Asian for: } \\
\hline & Math & Reading & Math & Reading & Math & Reading \\
\hline Baseline & $-.094(.023)$ & $.117(.025)$ & $-.203(.022)$ & $-.064(.025)$ & $.265(.048)$ & $.409(.058)$ \\
\hline Unweighted & $-.100(.023)$ & $.092(.024)$ & $-.206(.021)$ & $-.057(.024)$ & $.285(.034)$ & $.387(.035)$ \\
\hline \multicolumn{7}{|c|}{ Other test score measures } \\
\hline T-scores & $-.050(.024)$ & $.141(.030)$ & $-.057(.022)$ & $.065(.028)$ & $.176(.040)$ & $.298(.048)$ \\
\hline \multicolumn{7}{|l|}{ By Gender } \\
\hline Males & $-.126(.034)$ & $.093(.037)$ & $-.224(.032)$ & $-.095(.035)$ & $.338(.078)$ & $.385(.087)$ \\
\hline Females & $-.058(.030)$ & $.147(.035)$ & $-.181(.031)$ & $-.035(.036)$ & $.203(.059)$ & $.433(.077)$ \\
\hline \multicolumn{7}{|l|}{ By SES Quintile: } \\
\hline Bottom & $-.092(.044)$ & $-.005(.041)$ & $-.202(.044)$ & $-.133(.045)$ & $.328(.143)$ & $.043(.111)$ \\
\hline Second & $-.088(.045)$ & $.091(.049)$ & $-.179(.046)$ & $-.090(.047)$ & $.044(.106)$ & $-.001(.090)$ \\
\hline Third & $-.097(.049)$ & $.068(.045)$ & $-.242(.046)$ & $-.106(.051)$ & $.249(.121)$ & $.351(.167)$ \\
\hline Fourth & $-.082(.058)$ & $.292(.077)$ & $-.100(.056)$ & $.030(.057)$ & $.207(.088)$ & $.396(.115)$ \\
\hline Top & $-.169(.080)$ & $.068(.085)$ & $-.323(.078)$ & $-.113(.094)$ & $.404(.087)$ & $.724(.102)$ \\
\hline \multicolumn{7}{|l|}{ By family structure: } \\
\hline Single mother & $-.087(.043)$ & $.070(.043)$ & $-.197(.048)$ & $-.119(.047)$ & $.086(.149)$ & $.114(.144)$ \\
\hline $\begin{array}{l}\text { Two biological } \\
\text { parents }\end{array}$ & $-.127(.034)$ & $.141(.042)$ & $-.176(.029)$ & $-.033(.033)$ & $.291(.054)$ & $.456(.064)$ \\
\hline $\begin{array}{l}\text { Teen mother at } 1^{\text {st }} \\
\text { birth }\end{array}$ & $-.101(.036)$ & $.014(.033)$ & $-.199(.036)$ & $-.127(.038)$ & $.170(.105)$ & $.251(.114)$ \\
\hline $\begin{array}{l}\text { Teen mother at } \\
\text { child's birth }\end{array}$ & $-.062(.046)$ & $-.021(.043)$ & $-.196(.045)$ & $-.105(.052)$ & $.279(.141)$ & $.281(.135)$ \\
\hline \multicolumn{7}{|l|}{ By location type: } \\
\hline Central city & $-.110(.035)$ & $.147(.040)$ & $-.235(.033)$ & $-.073(.037)$ & $.271(.061)$ & $.439(.075)$ \\
\hline Suburban & $-.135(.039)$ & $.030(.041)$ & $-.261(.041)$ & $-.145(.042)$ & $.146(.102)$ & $.310(.119)$ \\
\hline Rural & $-.184(.048)$ & $-.032(.050)$ & $-.253(.062)$ & $-.124(.072)$ & $.255(.130)$ & $.126(.102)$ \\
\hline \multicolumn{7}{|l|}{ By school type: } \\
\hline Public & $-.106(.024)$ & $.098(.027)$ & $-.214(.024)$ & $-.081(.027)$ & $.260(.051)$ & $.392(.064)$ \\
\hline Private & $.022(.070)$ & $.281(.074)$ & $-.152(.058)$ & $.015(.066)$ & $.296(.135)$ & $.479(.137)$ \\
\hline $\begin{array}{l}\text { School }>80 \% \\
\text { Black }\end{array}$ & $.053(.269)$ & $-.016(.215)$ & $-.084(.298)$ & $.057(.273)$ & $.285(.382)$ & $.788(.641)$ \\
\hline
\end{tabular}




\begin{tabular}{|l|l|l|l|l|l|l|}
\hline $\begin{array}{l}\text { School }>80 \% \\
\text { White }\end{array}$ & $-.105(.047)$ & $.059(.053)$ & $-.186(.025)$ & $-.061(.028)$ & $.288(.054)$ & $.436(.065)$ \\
\hline
\end{tabular}

Notes: Specifications in this table are variations on those reported in columns 4 and 9 of Table 2. Only the race coefficients are reported in this table. The top row of the table simply reproduces the baseline results in columns 4 and 9 of Table 2. The remaining rows of the table correspond to different weights, test score measures, or particular subsets of the data. For further details of the baseline specification, see the notes to Table 2 . 
Table 4: Estimates of the Responsiveness of Test Scores to Covariates by Race

\begin{tabular}{|c|c|c|c|c|c|c|c|c|c|c|}
\hline \multirow{2}{*}{ Variables } & \multicolumn{5}{|c|}{ Math } & \multicolumn{5}{|c|}{ Reading } \\
\hline & $\begin{array}{l}\text { Full } \\
\text { Sample }\end{array}$ & White & Black & Asian & Hispanic & $\begin{array}{l}\text { Full } \\
\text { Sample }\end{array}$ & White & Black & Asian & Hispanic \\
\hline Black & $\begin{array}{l}-.094 \\
(.023) \\
\end{array}$ & --- & --- & --- & --- & $\begin{array}{l}.117 \\
(.025) \\
\end{array}$ & --- & --- & --- & --- \\
\hline Hispanic & $\begin{array}{l}-.203 \\
(.022) \\
\end{array}$ & --- & --- & --- & --- & $\begin{array}{l}-.064 \\
(.025)\end{array}$ & --- & -- & -- & -- \\
\hline Asian & $\begin{array}{l}.265 \\
(.048) \\
\end{array}$ & --- & --- & --- & --- & $\begin{array}{l}.409 \\
(.058) \\
\end{array}$ & --- & --- & --- & --- \\
\hline Other race & $\begin{array}{l}-.158 \\
(.035) \\
\end{array}$ & --- & --- & --- & --- & $\begin{array}{l}-.072 \\
(.038) \\
\end{array}$ & --- & --- & --- & --- \\
\hline $\begin{array}{l}\text { Socio-economic status } \\
\text { composite measure }\end{array}$ & $\begin{array}{r}.302 \\
(.014) \\
\end{array}$ & $\begin{array}{l}.347 \\
(.020) \\
\end{array}$ & $\begin{array}{l}.193 \\
(.030) \\
\end{array}$ & $\begin{array}{r}.400 \\
(.071) \\
\end{array}$ & $.212(.031)$ & $\begin{array}{r}.299 \\
(.015) \\
\end{array}$ & $\begin{array}{l}.326 \\
(.020) \\
\end{array}$ & $\begin{array}{r}.217 \\
(.033) \\
\end{array}$ & $\begin{array}{r}.556 \\
(.080) \\
\end{array}$ & $\begin{array}{l}.203 \\
(.038) \\
\end{array}$ \\
\hline Number of Books & $\begin{array}{r}.006 \\
(.001) \\
\end{array}$ & $\begin{array}{l}.005 \\
(.001) \\
\end{array}$ & $\begin{array}{r}.005 \\
(.001) \\
\end{array}$ & $\begin{array}{l}.011 \\
(.003) \\
\end{array}$ & $.009(.001)$ & $\begin{array}{l}.006 \\
(.001) \\
\end{array}$ & $\begin{array}{r}.006 \\
(.001) \\
\end{array}$ & $\begin{array}{l}.004 \\
(.001) \\
\end{array}$ & $\begin{array}{r}.012 \\
(.004) \\
\end{array}$ & $\begin{array}{l}.007 \\
(.002) \\
\end{array}$ \\
\hline $\begin{array}{l}\text { (Number of Books) (squared) } \\
(* 1000)\end{array}$ & $\begin{array}{l}-.020 \\
(.002) \\
\end{array}$ & $\begin{array}{l}-.017 \\
(.003) \\
\end{array}$ & $\begin{array}{l}-.017 \\
(.007) \\
\end{array}$ & $\begin{array}{l}-.040 \\
(.015) \\
\end{array}$ & $\begin{array}{l}-.032 \\
(.006) \\
\end{array}$ & $\begin{array}{l}-.021 \\
(.003) \\
\end{array}$ & $\begin{array}{l}-.020 \\
(.003) \\
\end{array}$ & $\begin{array}{l}-.012 \\
(.010) \\
\end{array}$ & $\begin{array}{l}-.044 \\
(.018) \\
\end{array}$ & $\begin{array}{l}-.025 \\
(.008) \\
\end{array}$ \\
\hline Female & $\begin{array}{l}.010 \\
(.015) \\
\end{array}$ & $\begin{array}{l}.003 \\
(.021) \\
\end{array}$ & $\begin{array}{c}.058 \\
(.033) \\
\end{array}$ & $\begin{array}{l}-.151 \\
(.096)\end{array}$ & $.029(.032)$ & $\begin{array}{l}.159 \\
(.017) \\
\end{array}$ & $\begin{array}{l}.170 \\
(.022) \\
\end{array}$ & $\begin{array}{l}.146 \\
(.038) \\
\end{array}$ & $\begin{array}{l}.152 \\
(.113) \\
\end{array}$ & $\begin{array}{l}.163 \\
(.043) \\
\end{array}$ \\
\hline $\begin{array}{l}\text { Age at kindergarten fall (in } \\
\text { months) }\end{array}$ & $\begin{array}{c}.056 \\
(.002) \\
\end{array}$ & $\begin{array}{l}.061 \\
(.003) \\
\end{array}$ & $\begin{array}{r}.045 \\
(.004) \\
\end{array}$ & $\begin{array}{l}.074 \\
(.015) \\
\end{array}$ & $.051(.004)$ & $\begin{array}{l}.041 \\
(.002) \\
\end{array}$ & $\begin{array}{r}.044 \\
(.003) \\
\end{array}$ & $\begin{array}{l}.035 \\
(.004) \\
\end{array}$ & $\begin{array}{r}.052 \\
(.018) \\
\end{array}$ & $\begin{array}{l}.035 \\
(.005) \\
\end{array}$ \\
\hline Birth weight (ounces) $(* 10)$ & $\begin{array}{r}.029 \\
(.004) \\
\end{array}$ & $\begin{array}{l}.037 \\
(.005) \\
\end{array}$ & $\begin{array}{r}.023 \\
(.007) \\
\end{array}$ & $\begin{array}{c}.084 \\
(.032) \\
\end{array}$ & $.002(.009)$ & $\begin{array}{r}.019 \\
(.004) \\
\end{array}$ & $\begin{array}{c}.024 \\
(.005) \\
\end{array}$ & $\begin{array}{c}.021 \\
(.009) \\
\end{array}$ & $\begin{array}{r}.088 \\
(.045) \\
\end{array}$ & $\begin{array}{l}-.012 \\
(.010) \\
\end{array}$ \\
\hline $\begin{array}{l}\text { Teenage mother at time of first } \\
\text { birth }\end{array}$ & $\begin{array}{l}-.109 \\
(.018) \\
\end{array}$ & $\begin{array}{l}-.126 \\
(.030) \\
\end{array}$ & $\begin{array}{l}-.127 \\
(.036) \\
\end{array}$ & $\begin{array}{l}-.113 \\
(.123) \\
\end{array}$ & $\begin{array}{l}-.073 \\
(.033) \\
\end{array}$ & $\begin{array}{l}-.144 \\
(.020) \\
\end{array}$ & $\begin{array}{l}-.117 \\
(.029) \\
\end{array}$ & $\begin{array}{l}-.219 \\
(.041) \\
\end{array}$ & $\begin{array}{l}-.022 \\
(.144) \\
\end{array}$ & $\begin{array}{l}-.129 \\
(.044) \\
\end{array}$ \\
\hline $\begin{array}{l}\text { Mother at least } 30 \text { at time of } \\
\text { first birth }\end{array}$ & $\begin{array}{l}.182 \\
(.025) \\
\end{array}$ & $\begin{array}{r}.174 \\
(.030) \\
\end{array}$ & $\begin{array}{c}.106 \\
(.071) \\
\end{array}$ & $\begin{array}{c}.233 \\
(.118) \\
\end{array}$ & $.178(.066)$ & $\begin{array}{r}.226 \\
(.027) \\
\end{array}$ & $\begin{array}{r}.206 \\
(.031) \\
\end{array}$ & $\begin{array}{r}.231 \\
(.095) \\
\end{array}$ & $\begin{array}{c}.132 \\
(.145) \\
\end{array}$ & $\begin{array}{c}.348 \\
(.085) \\
\end{array}$ \\
\hline WIC Participant & $\begin{array}{c}-.211 \\
(.019) \\
\end{array}$ & $\begin{array}{c}-.204 \\
(.027) \\
\end{array}$ & $\begin{array}{l}-.173 \\
(.047) \\
\end{array}$ & $\begin{array}{c}-.087 \\
(.108) \\
\end{array}$ & $\begin{array}{c}-.198 \\
(.039) \\
\end{array}$ & $\begin{array}{c}-.184 \\
(.021) \\
\end{array}$ & $\begin{array}{l}-.177 \\
(.027) \\
\end{array}$ & $\begin{array}{l}-.147 \\
(.056) \\
\end{array}$ & $\begin{array}{c}-.203 \\
(.124) \\
\end{array}$ & $\begin{array}{c}-.184 \\
(.049) \\
\end{array}$ \\
\hline R-squared & 0.317 & .227 & .194 & .300 & .301 & 0.233 & .189 & .181 & .285 & .234 \\
\hline Number of Obs. & 13290 & 7,999 & 1,806 & 537 & 2,234 & 12601 & 8,000 & 1,804 & 536 & 1,546 \\
\hline
\end{tabular}

Notes: The dependent variable is the math or reading test score in the fall of kindergarten. The first and sixth columns simply replicate our 
baseline results from columns 4 and 9 of Table 2. The other columns report coefficient estimates from specifications identical to that of the baseline, but estimated separately by race of the student. There is no within-race variation in the race variables, so these variables are omitted from the within-race regressions. See the notes to Table 2 for further details of the estimation. 
Table 5: The Evolution of Test Score Gaps by Race as Children Age

\begin{tabular}{|c|c|c|c|c|}
\hline \multirow{2}{*}{ Variables } & \multicolumn{2}{|c|}{ Math } & \multicolumn{2}{|c|}{ Reading } \\
\hline & Fall kindergarten & Spring first grade & Fall kindergarten & Spring first grade \\
\hline Black & $-.094(.023)$ & $-.250(.028)$ & $.117(.025)$ & $-.071(.029)$ \\
\hline Hispanic & $-.203(.022)$ & $-.120(.026)$ & $-.064(.025)$ & $.001(.029)$ \\
\hline Asian & $.265(.048)$ & $.115(.044)$ & $.409(.058)$ & $.345(.045)$ \\
\hline Other race & $-.158(.035)$ & $-.195(.042)$ & $-.072(.038)$ & $-.163(.042)$ \\
\hline SES composite measure & $.302(.014)$ & $.263(.014)$ & $.299(.015)$ & $.284(.014)$ \\
\hline Number of Books & $.006(.001)$ & $.005(.001)$ & $.006(.001)$ & $.006(.001)$ \\
\hline (Number of Books) (squared) $(* 1000)$ & $.020(.002)$ & $-.019(.003)$ & $-.021(.003)$ & $-.022(.003)$ \\
\hline Female & $.010(.015)$ & $-.033(.017)$ & $.159(.017)$ & $.216(.017)$ \\
\hline Age at kindergarten fall (in months) & $.056(.002)$ & $.036(.002)$ & $.041(.002)$ & $.021(.002)$ \\
\hline Birth weight (ounces) $(* 10)$ & $.029(.004)$ & $.029(.004)$ & $.019(.004)$ & $.024(.005)$ \\
\hline Teenage mother at time of first birth & $-.109(.018)$ & $-.111(.022)$ & $-.144(.020)$ & $-.131(.024)$ \\
\hline Mother in 30s at time of first birth & $.182(.025)$ & $.093(.022)$ & $.226(.027)$ & $.085(.024)$ \\
\hline WIC Participant & $-.211(.019)$ & $-.201(.021)$ & $-.184(.021)$ & $-.182(.022)$ \\
\hline R-squared & 0.317 & .240 & 0.233 & .194 \\
\hline Number of Obs. & 13290 & 13,290 & 12601 & 12,601 \\
\hline
\end{tabular}

Notes: The dependent variable is fall kindergarten test scores in columns 1 and 3 and spring first grade test scores in columns 2 and 4 . All specifications include the parsimonious set of controls corresponding to columns 4 and 9 of Table 2 . Test scores are IRT scores, normalized to have a mean of zero and a standard deviation of one in the full, unweighted sample. Non-Hispanic Whites are the omitted race category, so all of the race coefficients are gaps relative to that group. The unit of observation is a student. Standard errors in parentheses. Estimation is done using weighted least squares, using sample weights provided in the data set. In addition to the variables included in the table, indicator variables for students with missing values on each covariate are also included in the regressions. 
Table 6: Does Differential School Quality Explain Black Students Losing Ground:

A comparison of cross-school and within-school estimates of the test score trajectory by race (Values reported in table are the coefficient on the variable Black)

\begin{tabular}{|c|c|c|c|c|c|c|c|c|c|}
\hline \multirow{3}{*}{ Subject } & \multicolumn{3}{|c|}{ Full Sample of Students } & \multicolumn{6}{|c|}{ Excluding Students Attending All White Schools } \\
\hline & (1) & (2) & (3) & (4) & $(5)$ & $(6)$ & (7) & (8) & (9) \\
\hline & $\begin{array}{l}\text { Fall } \\
\text { Kinder- } \\
\text { garten }\end{array}$ & $\begin{array}{l}\text { Spring } \\
\text { first } \\
\text { grade }\end{array}$ & $\begin{array}{l}\text { Difference } \\
(2)-(1)\end{array}$ & $\begin{array}{l}\text { Fall } \\
\text { Kinder- } \\
\text { garten }\end{array}$ & $\begin{array}{l}\text { Spring } \\
\text { first } \\
\text { grade }\end{array}$ & $\begin{array}{l}\text { Difference } \\
(5)-(4)\end{array}$ & $\begin{array}{l}\text { Fall } \\
\text { Kinder- } \\
\text { garten }\end{array}$ & $\begin{array}{l}\text { Spring first } \\
\text { grade }\end{array}$ & $\begin{array}{l}\text { Difference } \\
(8)-(7)\end{array}$ \\
\hline Math & $\begin{array}{l}-.094 \\
(.023)\end{array}$ & $\begin{array}{l}-.250 \\
(.028)\end{array}$ & $\begin{array}{l}-.156 \\
(.036)\end{array}$ & $\begin{array}{l}-.136 \\
(.028)\end{array}$ & $\begin{array}{l}-.261 \\
(.034)\end{array}$ & $\begin{array}{l}-.125 \\
(.044)\end{array}$ & $\begin{array}{l}-.175 \\
(.034)\end{array}$ & $\begin{array}{l}-.222 \\
(.040)\end{array}$ & $\begin{array}{l}-.047 \\
(.052)\end{array}$ \\
\hline Reading & $\begin{array}{l}.117 \\
(.025)\end{array}$ & $\begin{array}{c}-.071 \\
(.029)\end{array}$ & $\begin{array}{c}-.188 \\
(.038)\end{array}$ & $\begin{array}{c}.072 \\
(.030)\end{array}$ & $\begin{array}{l}-.084 \\
(.035)\end{array}$ & $\begin{array}{c}-.156 \\
(.046)\end{array}$ & $\begin{array}{l}-.007 \\
(.038)\end{array}$ & $\begin{array}{l}-.057 \\
(.042)\end{array}$ & $\begin{array}{c}-.05 \\
(.057)\end{array}$ \\
\hline $\begin{array}{l}\text { Include school-fixed } \\
\text { effects in } \\
\text { regression? }\end{array}$ & $\mathrm{N}$ & $\mathrm{N}$ & $\mathrm{N}$ & $\mathrm{N}$ & $\mathrm{N}$ & $\mathrm{N}$ & $\mathrm{Y}$ & $\mathrm{Y}$ & $\mathrm{Y}$ \\
\hline Number of Obs. & \multicolumn{3}{|c|}{13,290} & \multicolumn{6}{|c|}{6,532} \\
\hline
\end{tabular}

Notes: Entries in the table are estimates of the Black-White test score gap, controlling for the parsimonious set of regressors. Columns 3,6 , and 9 represent the estimated change in the gap between kindergarten fall and first grade spring. The first three columns include all students. The remaining columns restrict the data set to schools that had students of different races included in the ECLS-K sample. The final three columns include school-fixed effects. Estimation is done using weighted least squares, using sample weights provided in the data set. 
Table 7: Differences across Races in Measurable School Inputs

\begin{tabular}{|c|c|c|c|c|c|}
\hline \multirow{2}{*}{ School Input } & \multirow{2}{*}{ Mean of School Input } & \multicolumn{4}{|c|}{ Coefficient on Race in Predicting Level of School Input: } \\
\hline & & Black & Hispanic & Asian & Other \\
\hline Average Class Size & $20.673(3.875)$ & $.591(.340)$ & $.699(.271)$ & $.799(.349)$ & $-.259(.343)$ \\
\hline Teacher Has Master's Degree & $.280(.449)$ & $.037(.028)$ & $.012(.025)$ & $\begin{array}{l}-.001 \\
(.032)\end{array}$ & $-.080(.032)$ \\
\hline Computer:Student Ratio & $1.257(2.050)$ & $.003(.156)$ & $-.131(.140)$ & $.040(.119)$ & $.683(.443)$ \\
\hline Internet Hookup:Student Ratio & $.344(.627)$ & $-.048(.037)$ & $-.032(.038)$ & $.020(.035)$ & $.377(.186)$ \\
\hline $\begin{array}{l}\text { Percent of Students in School with Free } \\
\text { Lunch }\end{array}$ & $29.829(27.975)$ & $\begin{array}{l}19.321 \\
(2.604)\end{array}$ & $\begin{array}{l}8.173 \\
(1.996)\end{array}$ & $\begin{array}{l}3.271 \\
(2.076)\end{array}$ & $\begin{array}{l}6.815 \\
(2.780)\end{array}$ \\
\hline Gang Problems in School (1-3) & $1.409(.585)$ & $.261(.058)$ & $.338(.044)$ & $.128(.044)$ & $.336(.069)$ \\
\hline Problems with Teacher Turnover (1-5) & $1.811(.943)$ & $.263(.083)$ & $.227(.064)$ & $.062(.078)$ & $.132(.092)$ \\
\hline Litter Around School (0-3) & $.741(.759)$ & $.492(.065)$ & $.369(.053)$ & $.240(.063)$ & $.412(.087)$ \\
\hline People Loitering Around School (0-3) & $.524(.747)$ & $.497(.079)$ & $.331(.064)$ & $.171(.063)$ & $.368(.088)$ \\
\hline Receives PTA Funding & $.733(.442)$ & $-.048(.033)$ & $-.050(.026)$ & $.000(.029)$ & $-.133(.050)$ \\
\hline Hall Pass Required & $.425(.494)$ & $.194(.037)$ & $.100(.034)$ & $.010(.041)$ & $.059(.046)$ \\
\hline
\end{tabular}

Notes: The values in the first column of the table are the means and standard deviations of the named school input. The entries in the remaining columns are estimated coefficients on race (with non-Hispanic Whites as the omitted categories) from regressions of the named school inputs on the race dummies and other covariates included in the parsimonious set of controls. The method of estimation is weighted least squares using sample weights provided by ECLS. The reported standard errors have been corrected to take into account within-school correlation in the schoollevel measures. 
Table 8: Do Black Students Suffer a Greater Summer Setback when School is Not in Session? Estimates of the Black-White test score gap for the subset of the sample tested in Fall of first grade (Values in the table are coefficients on the variable Black)

\begin{tabular}{|c|c|c|c|c|}
\hline \multirow{2}{*}{ Subject } & \multicolumn{4}{|c|}{ Date test administered: } \\
\hline & Fall kindergarten & Spring kindergarten & Fall first grade & Spring first grade \\
\hline \multicolumn{5}{|l|}{ Raw Gaps } \\
\hline Math & $\begin{array}{l}-.601 \\
(.040)\end{array}$ & $\begin{array}{l}-.640 \\
(.044)\end{array}$ & $\begin{array}{l}-.631 \\
(.045)\end{array}$ & $\begin{array}{l}-.696 \\
(.048)\end{array}$ \\
\hline Reading & $\begin{array}{l}-.376 \\
(.042)\end{array}$ & $\begin{array}{l}-.421 \\
(.044) \\
\end{array}$ & $\begin{array}{c}-.390 \\
(.043) \\
\end{array}$ & $\begin{array}{l}-.548 \\
(.048)\end{array}$ \\
\hline \multicolumn{5}{|c|}{ With Controls } \\
\hline Math & $\begin{array}{l}-.052 \\
(.040)\end{array}$ & $\begin{array}{l}-.097 \\
(.044)\end{array}$ & $\begin{array}{l}-.134 \\
(.045) \\
\end{array}$ & $\begin{array}{l}-.236 \\
(.052) \\
\end{array}$ \\
\hline Reading & $\begin{array}{c}.142 \\
(.043)\end{array}$ & $\begin{array}{c}.054 \\
(.045) \\
\end{array}$ & $\begin{array}{c}.071 \\
(.044)\end{array}$ & $\begin{array}{l}-.081 \\
(.051) \\
\end{array}$ \\
\hline
\end{tabular}

Notes: Table entries are estimated Black-White test score gaps at different points in time for the subset of the sample that has all four test scores. Only a small fraction of the sample was tested in Fall of first grade. The total number of observations in the sub-sample is 5,223. The top panel of the table reflects raw test score gaps; the bottom panel is the residual test score gap, controlling for the parsimonious set of control variables. The observations demarcated by the heavy border represent the tests given shortly before and shortly after summer break. Standard errors are in parentheses. 
Table 9: The Evolution of the Performance Gap on Subjective Teacher Assessments for Blacks, Hispanics, and Asians (All gaps measured relative to Whites)

\begin{tabular}{|c|c|c|c|c|c|c|}
\hline \multirow{2}{*}{$\begin{array}{l}\text { Teacher's subjective } \\
\text { assessment of student } \\
\text { ability in: }\end{array}$} & \multicolumn{2}{|c|}{ Black-White gap } & \multicolumn{2}{|c|}{ Hispanic-White gap } & \multicolumn{2}{|c|}{ Asian-White gap } \\
\hline & Raw data & $\begin{array}{l}\text { Including all } \\
\text { controls }\end{array}$ & Raw data & $\begin{array}{l}\text { Including all } \\
\text { controls }\end{array}$ & Raw data & $\begin{array}{l}\text { Including all } \\
\text { controls }\end{array}$ \\
\hline \multicolumn{7}{|l|}{ Math } \\
\hline Kindergarten fall & $-.278(.039)$ & $-.103(.038)$ & $-.243(.037)$ & $-.097(.034)$ & $-.001(.050)$ & $.104(.046)$ \\
\hline First grade spring & $-.463(.062)$ & $-.270(.060)$ & $-.242(.049)$ & $-.076(.048)$ & $.142(.063)$ & $.262(.061)$ \\
\hline \multicolumn{7}{|l|}{ Reading } \\
\hline Kindergarten fall & $-.265(.041)$ & $-.066(.040)$ & $-.352(.038)$ & $-.177(.034)$ & $-.148(.053)$ & $-.041(.049)$ \\
\hline First grade spring & $-.343(.057)$ & $-.146(.054)$ & $-.288(.047)$ & $-.101(.045)$ & $.063(.062)$ & $.190(.058)$ \\
\hline
\end{tabular}

Notes: The table entries are estimated racial gaps in subjective teacher assessments of student achievement provided by teachers in kindergarten fall and first-grade spring. The odd columns are raw gaps; the even columns are residual gaps after controlling for the parsimonious set of controls and teacher-fixed effects. Teacher-fixed effects are included in the regressions due to concerns over comparability across teachers in these assessments. Teacher assessments are normalized to have a mean of zero and a standard deviation of one in the full, unweighted sample. The method of estimation is weighted least squares using sample weights provided by ECLS. Columns 2, 4, and 6 of each row are coefficients from one regression. The number of observations is 8,633 for math and 10,839 for reading. 
Table 10: Differences in the Evolution of the Test-Score Gap by Teacher's Race

\begin{tabular}{|c|c|c|c|c|}
\hline \multirow{2}{*}{ Subject } & \multicolumn{2}{|c|}{$\begin{array}{l}\text { Neither Kindergarten nor first grade } \\
\text { teacher is Black }\end{array}$} & \multicolumn{2}{|c|}{$\begin{array}{l}\text { At least one of Kindergarten or first } \\
\text { grade teacher is Black }\end{array}$} \\
\hline & $\begin{array}{c}\text { Fall } \\
\text { kindergarten }\end{array}$ & Spring first grade & Fall kindergarten & Spring first grade \\
\hline Math & $-.134(.031)$ & $-.251(.036)$ & $-.149(.079)$ & $-.378(.085)$ \\
\hline Reading & $.081(.038)$ & $-.072(.037)$ & $.163(.073)$ & $-.172(.085)$ \\
\hline \multicolumn{5}{|l|}{ Full Sample (with fixed effects) } \\
\hline Math & $-.162(.041)$ & $-.237(.045)$ & $-.218(.098)$ & $-.367(.113)$ \\
\hline Reading & $-.015(.048)$ & $-.053(.048)$ & $.115(.109)$ & $-.182(.116)$ \\
\hline \multicolumn{5}{|c|}{ Teacher Assessments (with fixed effects) } \\
\hline Math Teacher Assessment & $-.125(.053)$ & $-.206(.051)$ & $-.154(.102)$ & $-.299(.136)$ \\
\hline Reading Teacher Assessment & $-.135(.048)$ & $-.109(.052)$ & $-.183(.112)$ & $-.248(.142)$ \\
\hline Number of White observations & \multicolumn{2}{|c|}{6,885} & \multicolumn{2}{|c|}{371} \\
\hline Number of Black observations & \multicolumn{2}{|c|}{863} & \multicolumn{2}{|c|}{1,170} \\
\hline
\end{tabular}

Notes: The values in the table are estimated Black-White test score gaps in the top two panels and subjective teacher assessments in the third panel. Students in the data set are assigned to two mutually exclusive groups in this table: students who do/do not have any Black teachers in kindergarten or first grade. The number of observations falling into each of those categories, by race of the student, is reported at the bottom of the table. The top panel of the table reports results from regressions including the parsimonious set of controls. The second panel adds teacherfixed effects. The bottom panel is teacher assessments, controlling for teacher-fixed effects. 
Table 11: Black-White Performance Gaps on Questions Assessing Specific Sets of Skills

\begin{tabular}{|c|c|c|}
\hline \multirow{2}{*}{ Skill tested } & \multicolumn{2}{|c|}{ Black-White gap on these questions } \\
\hline & Fall kindergarten & Spring first grade \\
\hline \multicolumn{3}{|l|}{ Math } \\
\hline Count, Number, Shapes & $.042(.030)$ & $-.020(.045)$ \\
\hline Relative Size & $-.108(.028)$ & $-.035(.038)$ \\
\hline Ordinality, Sequence & $-.108(.023)$ & $-.067(.035)$ \\
\hline Add/Subtract & $-.056(.018)$ & $-.232(.031)$ \\
\hline Multiply/Divide & $.005(.011)$ & $-.262(.023)$ \\
\hline \multicolumn{3}{|l|}{ Reading } \\
\hline Letter Recognition & $.114(.030)$ & $.033(.047)$ \\
\hline Beginning Sounds & $.099(.027)$ & $-.038(.036)$ \\
\hline Ending Sounds & $.107(.025)$ & $-.068(.034)$ \\
\hline Sight Words & $.072(.025)$ & $-.090(.033)$ \\
\hline Words in Context & $.057(.022)$ & $-.061(.029)$ \\
\hline
\end{tabular}

Notes: Entries in the table are residual Black-White test score gaps on specific types of questions in kindergarten fall and first-grade spring. On each category of question, student scores have been normalized to have a mean of zero and standard deviation equal to one in the full, unweighted sample. The parsimonious set of controls is included in all regressions. The method of estimation is weighted least squares using sample weights provided by ECLS. The number of observations on reading is 13,290 and on math is 12,601. 
Appendix Table 1: Summary Statistics by Race: Student Characteristics

\begin{tabular}{|c|c|c|}
\hline Variable & Black & White \\
\hline \multicolumn{3}{|l|}{ Baseline child characteristics } \\
\hline Female & $.495(.536)$ & $.481(.594)$ \\
\hline Age, fall of kindergarten & $\begin{array}{l}66.877 \\
(4.776)\end{array}$ & $\begin{array}{l}67.402 \\
(4.752)\end{array}$ \\
\hline \multicolumn{3}{|l|}{ Geography } \\
\hline Northeast region & $.134(.341)$ & $.214(.396)$ \\
\hline Midwest region & $.170(.390)$ & $.285(.495)$ \\
\hline South region & $.613(.536)$ & $.344(.495)$ \\
\hline West region & $.083(.292)$ & $.156(.396)$ \\
\hline Urban & $.533(.536)$ & $.418(.495)$ \\
\hline Suburban & $.359(.536)$ & $.323(.495)$ \\
\hline Rural & $.108(.341)$ & $.260(.495)$ \\
\hline \multicolumn{3}{|l|}{ Family composition } \\
\hline Two parents, both biological & $.317(.536)$ & $.738(.495)$ \\
\hline Two parents, one biological & $.083(.292)$ & $.091(.297)$ \\
\hline Single parent & $.502(.536)$ & $.147(.396)$ \\
\hline Adopted & $.019(.146)$ & $.011(.099)$ \\
\hline In custody of guardian & $.079(.292)$ & $.013(.099)$ \\
\hline Number of siblings in home & $1.595(1.462)$ & $\begin{array}{l}1.369 \\
(1.089)\end{array}$ \\
\hline Mother's age at first birth & $\begin{array}{l}20.548 \\
(5.139)\end{array}$ & $\begin{array}{l}24.579 \\
(5.916)\end{array}$ \\
\hline Mother age at this child's birth & $\begin{array}{l}26.587 \\
(9.169)\end{array}$ & $\begin{array}{l}28.046 \\
(6.760)\end{array}$ \\
\hline \multicolumn{3}{|l|}{ Parental education and income } \\
\hline Mother's level of education & $\begin{array}{l}12.682 \\
(2.130)\end{array}$ & $\begin{array}{l}13.861 \\
(2.454)\end{array}$ \\
\hline Father's level of education & $\begin{array}{l}12.964 \\
(2.246)\end{array}$ & $\begin{array}{l}13.993 \\
(2.798)\end{array}$ \\
\hline SES measure & $-.359(.780)$ & $.202(.792)$ \\
\hline WIC participation & $.772(.481)$ & $.332(.493)$ \\
\hline
\end{tabular}




\begin{tabular}{|c|c|c|}
\hline Food stamp participation & $.451(.533)$ & $.103(.395)$ \\
\hline Mother's occupational status & $\begin{array}{l}40.642 \\
(10.512)\end{array}$ & $\begin{array}{l}44.930 \\
(12.648)\end{array}$ \\
\hline Father's occupational status & $\begin{array}{l}39.698 \\
(9.076)\end{array}$ & $\begin{array}{l}44.111 \\
(11.949)\end{array}$ \\
\hline \multicolumn{3}{|l|}{ Child's early home environment } \\
\hline Child's birth weight (in ounces) & $\begin{array}{l}110.315 \\
(25.373)\end{array}$ & $\begin{array}{l}120.256 \\
(22.942)\end{array}$ \\
\hline Working mother & $.817(.420)$ & $.770(.487)$ \\
\hline No-Non Parental Care & $.135(.384)$ & $.171(.394)$ \\
\hline Relative Care & $.179(.432)$ & $.110(.296)$ \\
\hline Non-Relative Care & $.041(.240)$ & $.126(.394)$ \\
\hline Center-Based Program & $.337(.528)$ & $.493(.591)$ \\
\hline Head Start participation & $.227(.480)$ & $.055(.296)$ \\
\hline \multicolumn{3}{|l|}{ Varied } \\
\hline English spoken at home & $.991(.097)$ & $.986(.099)$ \\
\hline Number of books in home & $\begin{array}{l}39.014 \\
(41.986) \\
\end{array}$ & $\begin{array}{l}93.121 \\
(64.792)\end{array}$ \\
\hline \multicolumn{3}{|l|}{$\begin{array}{l}\text { Neighborhood characteristics (1="No } \\
\text { Problem", 3="Big Problem") }\end{array}$} \\
\hline $\begin{array}{l}\text { How big a problem is personal } \\
\text { safety? }\end{array}$ & $2.485(.633)$ & $2.783(.495)$ \\
\hline How big a problem are drugs? & $2.700(.632)$ & $2.931(.297)$ \\
\hline How big a problem is burglary? & $2.836(.486)$ & $2.897(.396)$ \\
\hline How big a problem is violence? & $2.907(.389)$ & $2.983(.198)$ \\
\hline $\begin{array}{l}\text { How big a problem are vacant } \\
\text { houses? }\end{array}$ & $2.860(.438)$ & $2.962(.297)$ \\
\hline \multicolumn{3}{|l|}{ Parental involvement } \\
\hline $\begin{array}{l}\text { How often does parent read books to } \\
\text { child? }\end{array}$ & $3.009(.924)$ & $3.352(.791)$ \\
\hline $\begin{array}{l}\text { How often does parent tell stories to } \\
\text { child? }\end{array}$ & $2.644(1.021)$ & $2.757(.989)$ \\
\hline $\begin{array}{l}\text { How often does parent take child to } \\
\text { library? }\end{array}$ & $.486(.535)$ & $.559(.594)$ \\
\hline
\end{tabular}




\begin{tabular}{|l|l|l|}
\hline $\begin{array}{l}\text { How often does parent take child to } \\
\text { museum? }\end{array}$ & $.285(.487)$ & $.329(.495)$ \\
\hline $\begin{array}{l}\text { How often does parent attend school } \\
\text { open houses? }\end{array}$ & $.593(.536)$ & $.792(.494)$ \\
\hline $\begin{array}{l}\text { How often does parent attend PTA } \\
\text { meetings? }\end{array}$ & $.357(.536)$ & $.334(.495)$ \\
\hline Kindergarten Program & \multicolumn{2}{|l|}{} \\
\hline Morning Program-Fall & $.128(.390)$ & $.295(.495)$ \\
\hline Afternoon Program-Fall & $.094(.341)$ & $.192(.396)$ \\
\hline All Day Program- Fall & $.777(.439)$ & $.513(.594)$ \\
\hline Morning Program-Spring & $.128(.379)$ & $.296(.682)$ \\
\hline Afternoon Program-Spring & $.089(.332)$ & $.192(.390)$ \\
\hline All Day Program- Spring & $.783(.474)$ & $.513(.585)$ \\
\hline $\begin{array}{l}\text { How often does parent volunteer at } \\
\text { school? }\end{array}$ & $.287(.487)$ & $.562(.495)$ \\
\hline $\begin{array}{l}\text { Frequency of missing values for key } \\
\text { variables }\end{array}$ & \multicolumn{2}{|l}{} \\
\hline Mother's age & $.045(.244)$ & $.008(.099)$ \\
\hline Mother's education & $.597(.536)$ & $.170(.396)$ \\
\hline Father's education & $.017(.099)$ \\
\hline Mother's Occupation & $.114(.396)$ \\
\hline Father's Occupation & $.328(.495)$ \\
\hline
\end{tabular}


Appendix Table 2: Full Regression Results of Baseline Specifications Fall kindergarten

\begin{tabular}{|c|c|c|}
\hline \multirow{2}{*}{ Variable } & Math & Reading \\
\hline & $\begin{array}{l}\text { Full } \\
\text { sample }\end{array}$ & $\begin{array}{l}\text { Full } \\
\text { sample }\end{array}$ \\
\hline \multicolumn{3}{|l|}{ Race } \\
\hline Black & $\begin{array}{l}-.102 \\
(.026)\end{array}$ & $\begin{array}{c}.093 \\
(.030)\end{array}$ \\
\hline Hispanic & $\begin{array}{l}-.171 \\
(.028)\end{array}$ & $\begin{array}{l}-.076 \\
(.029)\end{array}$ \\
\hline Asian & $.274(.050)$ & $\begin{array}{l}.375 \\
(.060)\end{array}$ \\
\hline Other & $\begin{array}{l}-.113 \\
(.035)\end{array}$ & $\begin{array}{l}-.014 \\
(.039)\end{array}$ \\
\hline \multicolumn{3}{|l|}{ Geographic controls } \\
\hline Northeast & $.070(.025)$ & $\begin{array}{l}.034 \\
(.027)\end{array}$ \\
\hline Midwest & $.021(.022)$ & $\begin{array}{c}-.047 \\
(.023)\end{array}$ \\
\hline West & $.060(.025)$ & $\begin{array}{c}.024 \\
(.028)\end{array}$ \\
\hline Rural & $\begin{array}{l}-.166 \\
(.022)\end{array}$ & $\begin{array}{l}-.186 \\
(.023)\end{array}$ \\
\hline Suburban & $\begin{array}{l}-.071 \\
(.018)\end{array}$ & $\begin{array}{l}-.094 \\
(.019)\end{array}$ \\
\hline \multicolumn{3}{|l|}{ Baseline child characteristics } \\
\hline Female & $.000(.015)$ & $\begin{array}{l}.153 \\
(.016)\end{array}$ \\
\hline Age (in months) & $\begin{array}{c}-2.680 \\
(.542)\end{array}$ & $\begin{array}{l}-2.409 \\
(.483)\end{array}$ \\
\hline Age (squared) & $.041(.008)$ & $\begin{array}{c}.037 \\
(.007)\end{array}$ \\
\hline Age (cubed x 1,000$)$ & $\begin{array}{l}-.209 \\
(.039)\end{array}$ & $\begin{array}{c}-.181 \\
(.033)\end{array}$ \\
\hline \multicolumn{3}{|l|}{ Home Environment } \\
\hline Sibling & $\begin{array}{l}-.058 \\
(.024)\end{array}$ & $\begin{array}{l}-.110 \\
(.027)\end{array}$ \\
\hline
\end{tabular}




\begin{tabular}{|c|c|c|}
\hline Sibling (squared) & $.004(.009)$ & $\begin{array}{c}.006 \\
(.010)\end{array}$ \\
\hline Sibling (cubed) & $\begin{array}{c}-.000 \\
(.001)\end{array}$ & $\begin{array}{c}.000 \\
(.001)\end{array}$ \\
\hline Biological mother/other father & $\begin{array}{c}-.031 \\
(.031)\end{array}$ & $\begin{array}{l}-.050 \\
(.031)\end{array}$ \\
\hline Other mother/biological father & $\begin{array}{c}-.101 \\
(.089)\end{array}$ & $\begin{array}{l}-.118 \\
(.080)\end{array}$ \\
\hline Biological mother only & $\begin{array}{c}-.033 \\
(.048)\end{array}$ & $\begin{array}{c}-.089 \\
(.058)\end{array}$ \\
\hline Biological father only & $.133(.152)$ & $\begin{array}{c}.010 \\
(.183)\end{array}$ \\
\hline Adopted & $\begin{array}{l}-.226 \\
(.065)\end{array}$ & $\begin{array}{l}-.056 \\
(.079)\end{array}$ \\
\hline Guardian & $\begin{array}{l}-.061 \\
(.088)\end{array}$ & $\begin{array}{l}-.023 \\
(.104)\end{array}$ \\
\hline Missing mother's age at $1^{\text {st }}$ birth & $\begin{array}{l}-.086 \\
(.059)\end{array}$ & $\begin{array}{l}-.100 \\
(.071)\end{array}$ \\
\hline Mother in her teens at $1^{\text {st }}$ birth & $.029(.021)$ & $\begin{array}{r}-.069 \\
(.022) \\
\end{array}$ \\
\hline Mother older than 30 at $1^{\text {st }}$ birth & $.111(.028)$ & $\begin{array}{c}.155 \\
(.030)\end{array}$ \\
\hline Missing mother's age at Child's birth & $\begin{array}{c}-.218 \\
(.104)\end{array}$ & $\begin{array}{c}-.064 \\
(.144)\end{array}$ \\
\hline Mother in her teens at child's birth & $\begin{array}{c}-.041 \\
(.024)\end{array}$ & $\begin{array}{l}-.022 \\
(.025)\end{array}$ \\
\hline Mother older than 30 at child's birth & $\begin{array}{c}-.016 \\
(.021)\end{array}$ & $\begin{array}{c}-.049 \\
(.021)\end{array}$ \\
\hline Mother high school graduate & $.048(.025)$ & $\begin{array}{r}.045 \\
(.026) \\
\end{array}$ \\
\hline Mother attended vocational school & $.129(.041)$ & $\begin{array}{r}.094 \\
(.043) \\
\end{array}$ \\
\hline Mother has some college & $.100(.032)$ & $\begin{array}{r}.086 \\
(.033) \\
\end{array}$ \\
\hline Mother has bachelor's degree & $.230(.041)$ & $\begin{array}{c}.178 \\
(.042)\end{array}$ \\
\hline Mother has graduate degree & $.279(.052)$ & $\begin{array}{c}.241 \\
(.056)\end{array}$ \\
\hline
\end{tabular}




\begin{tabular}{|c|c|c|}
\hline Missing mother's education & $.105(.119)$ & $\begin{array}{c}.032 \\
(.135)\end{array}$ \\
\hline Father high school graduate & $.064(.027)$ & $\begin{array}{c}.043 \\
(.030)\end{array}$ \\
\hline Father attended vocational school & $.093(.045)$ & $\begin{array}{c}.134 \\
(.053)\end{array}$ \\
\hline Father has some college & $.117(.033)$ & $\begin{array}{c}.099 \\
(.036)\end{array}$ \\
\hline Father has bachelor's degree & $.192(.039)$ & $\begin{array}{c}.169 \\
(.041)\end{array}$ \\
\hline Father has graduate degree & $.338(.051)$ & $\begin{array}{c}.303 \\
(.054)\end{array}$ \\
\hline Missing father's education & $.089(.055)$ & $\begin{array}{c}.146 \\
(.063)\end{array}$ \\
\hline Socio-economic status & $.072(.024)$ & $\begin{array}{c}.092 \\
(.023)\end{array}$ \\
\hline WIC & $\begin{array}{l}-.120 \\
(.020)\end{array}$ & $\begin{array}{c}-.104 \\
(.021)\end{array}$ \\
\hline Missing WIC & $\begin{array}{c}-.121 \\
(.085) \\
\end{array}$ & $\begin{array}{c}-.244 \\
(.102) \\
\end{array}$ \\
\hline Food Stamp & $\begin{array}{l}-.075 \\
(.022) \\
\end{array}$ & $\begin{array}{c}-.075 \\
(.024) \\
\end{array}$ \\
\hline Missing Food Stamp & $\begin{array}{c}-.044 \\
(.109) \\
\end{array}$ & $\begin{array}{r}-.000 \\
(.128)\end{array}$ \\
\hline Relative Pre-School Care & $.020(.027)$ & $\begin{array}{c}-.004 \\
(.029)\end{array}$ \\
\hline Non-Relative Pre-School Care & $.081(.032)$ & $\begin{array}{c}.036 \\
(.034)\end{array}$ \\
\hline Center-Based Pre-School Care & $.152(.023)$ & $\begin{array}{c}.150 \\
(.025) \\
\end{array}$ \\
\hline Head Start & $.016(.030)$ & $\begin{array}{c}-.043 \\
(.030) \\
\end{array}$ \\
\hline Varied Pre-School Care & $.112(.040)$ & $\begin{array}{c}.072 \\
(.041)\end{array}$ \\
\hline Missing Pre-School Care & $.196(.075)$ & $\begin{array}{c}.064 \\
(.072) \\
\end{array}$ \\
\hline Mother did not work between birth \& kindergarten & $.010(.021)$ & $\begin{array}{c}.004 \\
(.022)\end{array}$ \\
\hline
\end{tabular}




\begin{tabular}{|c|c|c|}
\hline $\begin{array}{l}\text { Missing whether mother worked between birth \& } \\
\text { kindergarten }\end{array}$ & $.018(.084)$ & $\begin{array}{l}-.023 \\
(.093)\end{array}$ \\
\hline Birth-weight (x 10) & $.030(.004)$ & $\begin{array}{l}.022 \\
(.004)\end{array}$ \\
\hline Missing birth-weight & $.279(.050)$ & $\begin{array}{l}.179 \\
(.053)\end{array}$ \\
\hline Neighborhood safety & $\begin{array}{l}-.115 \\
(.051)\end{array}$ & $\begin{array}{l}.024 \\
(.057)\end{array}$ \\
\hline Neighborhood drug use & $\begin{array}{l}-.060 \\
(.073)\end{array}$ & $\begin{array}{l}-.060 \\
(.082)\end{array}$ \\
\hline Neighborhood burglary & $.040(.080)$ & $\begin{array}{c}.066 \\
(.090)\end{array}$ \\
\hline Neighborhood violence & $.086(.112)$ & $\begin{array}{l}-.106 \\
(.136)\end{array}$ \\
\hline Neighborhood vacancies & $\begin{array}{l}-.046 \\
(.094)\end{array}$ & $\begin{array}{l}-.151 \\
(.103)\end{array}$ \\
\hline Mother's occupation & $.107(.056)$ & $\begin{array}{c}.070 \\
(.061)\end{array}$ \\
\hline Mother's occupation (squared) & $\begin{array}{l}-.002 \\
(.001)\end{array}$ & $\begin{array}{c}-.001 \\
(.001)\end{array}$ \\
\hline Mother's occupation (cubed x 1,000) & $.012(.007)$ & $\begin{array}{r}.008 \\
(.008) \\
\end{array}$ \\
\hline Missing mother's occupation & $\begin{array}{l}1.872 \\
(.918) \\
\end{array}$ & $\begin{array}{r}1.265 \\
(.990) \\
\end{array}$ \\
\hline Father's occupation & $\begin{array}{c}-.017 \\
(.046)\end{array}$ & $\begin{array}{c}.030 \\
(.048)\end{array}$ \\
\hline Father's occupation (squared) & $.000(.001)$ & $\begin{array}{c}-.001 \\
(.001)\end{array}$ \\
\hline Father's occupation (cubed x 1,000) & $\begin{array}{c}-.003 \\
(.006) \\
\end{array}$ & $\begin{array}{r}.003 \\
(.006) \\
\end{array}$ \\
\hline Missing father's occupation & $\begin{array}{c}-.209 \\
(.753) \\
\end{array}$ & $\begin{array}{r}.458 \\
(.791) \\
\end{array}$ \\
\hline English spoken in home & $.117(.031)$ & $\begin{array}{c}.091 \\
(.045)\end{array}$ \\
\hline Missing English & $\begin{array}{l}-.296 \\
(.187) \\
\end{array}$ & $\begin{array}{r}-.146 \\
(.203) \\
\end{array}$ \\
\hline Read book to child once or twice a week & $.071(.071)$ & $\begin{array}{l}-.070 \\
(.112)\end{array}$ \\
\hline
\end{tabular}




\begin{tabular}{|c|c|c|}
\hline Read book to child 3-6 times a week & $.091(.072)$ & $\begin{array}{l}-.061 \\
(.114)\end{array}$ \\
\hline Read book to child every day & $.135(.073)$ & $\begin{array}{c}.064 \\
(.114)\end{array}$ \\
\hline Missing read book & $.562(.226)$ & $\begin{array}{c}.479 \\
(.202)\end{array}$ \\
\hline Tell stories once or twice a week & $.074(.030)$ & $\begin{array}{c}.064 \\
(.032)\end{array}$ \\
\hline Tell stories 3-6 times a week & $.096(.032)$ & $\begin{array}{c}.056 \\
(.033)\end{array}$ \\
\hline Tell stories every day & $.026(.033)$ & $\begin{array}{c}.014 \\
(.035)\end{array}$ \\
\hline Missing tell story & $\begin{array}{l}-.293 \\
(.171)\end{array}$ & $\begin{array}{l}-.273 \\
(.157)\end{array}$ \\
\hline Number of books in home & $.005(.001)$ & $\begin{array}{c}.004 \\
(.001)\end{array}$ \\
\hline Number of books in home (squared x 1,000 ) & $\begin{array}{l}-.027 \\
(.016)\end{array}$ & $\begin{array}{c}-.017 \\
(.018)\end{array}$ \\
\hline Number of books in home (cubed x 1,000 ) & $.000(.000)$ & $\begin{array}{c}.000 \\
(.000) \\
\end{array}$ \\
\hline Missing number of books & $.251(.087)$ & $\begin{array}{c}.131 \\
(.088) \\
\end{array}$ \\
\hline Do not take child to library & $\begin{array}{c}-.047 \\
(.016)\end{array}$ & $\begin{array}{c}-.041 \\
(.017)\end{array}$ \\
\hline Missing library & $\begin{array}{l}-.389 \\
(.185)\end{array}$ & $\begin{array}{l}-.158 \\
(.260)\end{array}$ \\
\hline Do not take child to museum & $.018(.017)$ & $\begin{array}{c}.015 \\
(.018)\end{array}$ \\
\hline Missing museum & $\begin{array}{c}-.181 \\
(.226) \\
\end{array}$ & $\begin{array}{c}-.395 \\
(.337) \\
\end{array}$ \\
\hline Do not go to open house & $\begin{array}{c}-.030 \\
(.018) \\
\end{array}$ & $\begin{array}{r}-.000 \\
(.020) \\
\end{array}$ \\
\hline Missing open house & $\begin{array}{c}-.233 \\
(.135) \\
\end{array}$ & $\begin{array}{c}-.136 \\
(.142) \\
\end{array}$ \\
\hline Do not go to PTA & $\begin{array}{l}-.036 \\
(.017)\end{array}$ & $\begin{array}{l}-.038 \\
(.019)\end{array}$ \\
\hline Missing PTA & $.564(.243)$ & $\begin{array}{c}.542 \\
(.273)\end{array}$ \\
\hline
\end{tabular}




\begin{tabular}{|c|c|c|}
\hline Do not volunteer in school & $\begin{array}{l}-.061 \\
(.017)\end{array}$ & $\begin{array}{l}-.054 \\
(.018)\end{array}$ \\
\hline Missing volunteer & $\begin{array}{l}-.217 \\
(.190)\end{array}$ & $\begin{array}{l}-.376 \\
(.219)\end{array}$ \\
\hline Never spank child & $.037(.038)$ & $\begin{array}{c}.043 \\
(.042)\end{array}$ \\
\hline Spanked child 0 times last week & $.053(.035)$ & $\begin{array}{c}.038 \\
(.038)\end{array}$ \\
\hline Spanked child $\mathrm{x}$ times last week & $\begin{array}{c}-.027 \\
(.026)\end{array}$ & $\begin{array}{c}-.014 \\
(.028)\end{array}$ \\
\hline Spanked child $\mathrm{x}$ times last week (squared) & $.005(.003)$ & $\begin{array}{c}.003 \\
(.004)\end{array}$ \\
\hline Spanked child x times last week (cubed x 10) & $\begin{array}{c}-.002 \\
(.001)\end{array}$ & $\begin{array}{c}-.001 \\
(.001)\end{array}$ \\
\hline Missing spank & $\begin{array}{c}-.068 \\
(.092)\end{array}$ & $\begin{array}{c}.005 \\
(.113)\end{array}$ \\
\hline Morning Kindergarten Program- Fall & $\begin{array}{l}-.375 \\
(.116)\end{array}$ & $\begin{array}{l}-.386 \\
(.108)\end{array}$ \\
\hline Afternoon Kindergarten Program- Fall & $\begin{array}{c}-.443 \\
(.097)\end{array}$ & $\begin{array}{c}-.376 \\
(.116)\end{array}$ \\
\hline Morning Kindergarten Program- Spring & $.292(.116)$ & $\begin{array}{c}.280 \\
(.108)\end{array}$ \\
\hline Afternoon Kindergarten Program- Spring & $.376(.097$ & $\begin{array}{c}.297 \\
(.116)\end{array}$ \\
\hline
\end{tabular}




\section{Data Appendix}

The Early Childhood Longitudinal Study Kindergarten Cohort (ECLS-K) is a nationally representative sample of 21,260 children entering kindergarten in 1998. Thus far, information on these children has been gathered at four separate points in time. The full sample was interviewed in the fall and spring of kindergarten and spring of first grade. All of our regressions and summary statistics are weighted, unless otherwise noted, and we include dummies for missing data. We describe below how we combined and recoded some of the ECLS variables used in our analysis.

Socio-economic Composite Measure.

The socioeconomic scale variable (SES) was computed at the household level for the set of parents who completed the parent interview in Fall Kindergarten or Spring Kindergarten. The SES variable reflects the socioeconomic status of the household at the time of data collection for spring kindergarten. The components used for the creation of SES were: Father/male guardian's education; Mother/female guardian's education; Father/male guardian's occupation; Mother/female guardian's occupation; and Household income. Number of Children's Books.

Parents/guardians were asked " How many books does your child have in your home now, including library books?" Answers ranged from 0 to 200.

Child's Age.

We used the Child's Age at Assessment Composite variable provided by ECLS. The Child's age was calculated by determining the number of days between the child assessment date and the child's date of birth. The value was then divided by 30 to calculate the age in months.

\section{Birth Weight.}


Parent's were asked how much their child weighed when they were born. We multiplied the pounds by 16 (and added it to the ounces) to calculate birth weight in ounces.

Mother's Age at First Birth.

Mothers were asked how old they were at the birth of their first child.

Average Class Size.

We computed each child's average class size over their kindergarten year by adding their class size in the fall and spring and dividing by two.

Teacher Has Master's Degree.

We coded a dummy variable equal to one if the child's teacher has a master's degree or above. Computer-Student Ratio.

The number of computers in each school and the total enrollment of each kindergarten program is provided by the ECLS based on a survey given to each school. We divided the number of computers in each school by the total enrollment in kindergarten to produce this ratio.

Internet Hook-Up Student Ratio.

This was constructed similar to the Computer:Student ratio, except the numerator consists of internet/LAN connections in the school.

Percent of Students in Child's School Available for Free Lunch.

Schools provided the percent of students in their school who were eligible for free lunch.

Gang Problems.

Schools were asked "how much of a problem are gangs in the neighborhood where the school is located?" We coded this variable so that 1 implies "no problem", 2 implies "somewhat of a problem" and 3 implies "big problem."

\section{Teacher Turnover.}

Schools were asked how much they agreed with the statement "teacher turnover is a problem in 
this school." Answers range from 0-5, 0 indicating they strongly disagree and 5 indicating they strongly agree.

\section{Litter Around School.}

The ECLS interviewer was asked to report the amount of litter around each school. The variable ranges from 0 to 3. 0 indicates no litter and 3 indicates "a lot."

People Loitering Around School

The ECLS interviewer was asked to report the amount of loitering by non-students around the school. The variable ranges from 0 to 3. 0 indicates no litter and 3 indicates "a lot."

\section{PTA Funding.}

Schools reported whether or not they receive supplemental funding from their PTA. We recoded this variable so that 1 implies yes and 0 implies no.

Hall Pass Required.

Schools were asked "are hall passes required to ensure the safety of the children in your school?" This variable is coded 1 if yes and 0 if no. 
References

Armor, Greg. 1992. "Why is Black Educational Achievement Rising?" Public Interest. September,: pp. 65-80

Baron, Reuben, Tom, David, and Cooper, Harris. 1985. "Social Class, Race, and Teacher Expectations.” in Teacher Expectancies, Jerome Dusek, ed., Hillsdale, N.J.:Erlbaum

Baughman, E. and Dahlstrom, W. 1968. Negro and White Children: A psychological study in the Rural South. New York: Academic Press

Braken, Sabers, and Insko. 1987. "Performance of Black and White Children on the Bracken Basic Concept Scale.” Psychology in Schools, 24 (1): pp. 22-27..

Brooks-Gunn, Jeanne, Greg J. Duncan, Pamela Klebanov, and Naomi Sealand. 1993. "Do Neighborhoods Influence Child and Adolescent Development?" American Journal of Sociology, 99(2):353-95.

Brooks-Gunn, Jeanne, P.K. Klebanov, F. Liaw, and D. Spiker. 1993. "Enhancing the Development of Low Birth-Weight, Premature Infants: Changes in Cognition and Behavior over the First Three Years." Child Development 63:736-53.

Brooks-Gunn, Jeanne, Greg J. Duncan, and Pamela Klebanov. 1994. "Economic Deprivation and Early-Childhood Development," Child Development, 65(2): 296-318.

Brooks-Gunn, Jeanne, P.K. Klebanov, and G. K. Duncan. 1995. "Ethnic Differences in Children's Intelligence Test Scores: Role of Economic Deprivation, Home Environment, and Maternal Characteristics." Child Development 67(2): 396-408.

Brooks-Gunn, Jeanne, Greg J. Duncan, and Pamela Klebanov. 1996. "Ethnic Differences in Children's Intelligence Test Scores: Role of Economic Deprivation, Home Environment and Maternal Characteristics," Child Development 67, pp. 396-408.

Brooks-Gunn, Jeanne and Greg J. Duncan, eds. The Consequences of Growing Up Poor, (New York: Russell Sage, 1997).

Brooks-Gunn, Jeanne and Greg J. Duncan. 2000. "Family Poverty, Welfare Reform and Child Development," Child Development, 71(1): 188-196.

Caneiro, Pedro, Heckman, James, and Manoli, Dayanand. 2002. Human Capital Policy. Working Paper. The University of Chicago.

Coley, Richard J. 2002. "An Uneven Start: Indicators of Inequality in School Readiness," Educational Testing Service Report, March.

Cook, Michael, and Evans, William., 2000. "Families or Schools? Explaining the Convergence in White and Black Academic Performance ." Journal of Labor Economics, vol. 18, no. 4, p. 
729-54.

Cook, Phillip Ludwig, Jens. 1998. "The Burden of 'Acting White': Do Black Adolescents Disparage Academic Achievement?" in The Black-White Test Score Gap, C. Jencks and M. Phillips, eds. (Washington, DC: The Brookings Institute) pp. 375-400.

Coleman, James, and others. 1966. Equality of Educational Opportunity. Washington DC: U.S. Government Printing Office.

Currie, Janet, and Duncan Thomas. 1995. “Does Head Start Make a Difference?" American Economic Review, Vol. 85(3) p. 341-364.

Delpit, Lisa. 1995. Other Peoples Children: Cultural Conflict in the Classroom New York: The New Press.

Devlin, Bernie., Resnick, Daniel, and Roeder, Kathryn. 1998. Intelligence, Genes, and Success: Scientists Respond to the Bell Curve. Copernicus Books.

Dusek, Jerome B. 1975. “Do Teachers Bias Children's Learning?” Review of Educational Research 45:661-84.

Entwisle, Doris R. and Karl Alexander. 1992. "Summer Setback: Race, Poverty, School Composition, and Mathematics Achievement in the First Two Years of School." American Sociological Review 57:72-84.

Entwisle, Doris R. and Karl Alexander. 1994. "Winter Setback: The Racial Composition of Schools and Learning to Read." American Sociological Review 59:446-60.

Ferguson, Ronald F. "Teachers' Perceptions and Expectations and the Black-White Test Score Gap." in The Black-White Test Score Gap, C. Jencks and M. Phillips, eds. (Washington, DC: The Brookings Institute) pp. 273-317.

Fordham, Signithia and Ogbu, John. 1986 "Black Students' School Successes: Coping with the Burden of Acting White," The Urban Review 18 (3): 176-206.

Fraser, Steven. 1995. The Bell Curve Wars: Race Intelligence, and the Future of America. New York: Basic Books

Fryer, Roland. 2002 “Cultural Capital” Working Paper. University of Chicago.

Goldberg, Arthur and Manski, Charles. 1995. "Review Article: The Bell Curve." Journal of Economic Literature, 33 (2), pp. 762-776.

Grissmer, David., Flanagan, Ann, and Williamson, Stephanie., 1998. "Why Did the Black-White Score Gap Narrow in the 1970's and 1980's?" in The Black-White Test Score Gap, C. Jencks and M. Phillips, eds. (Washington, DC: The Brookings Institute) pp. 182-228 
Grogger, Jeffrey and Derek Neal. 2000. "Further Evidence on the Benefits of Catholic Secondary Schooling," Brookings-Wharton Papers on Urban Affairs, 1: 151-193.

Heckman, James J. 1995. “Lessons From The Bell Curve,” Journal of Political Economy, 103(5): 1091-1120

Hedges, Larry, and Nowell, Amy. 1998. "Black -White Test Score Convergence Since 1965" in The Black-White Test Score Gap, C. Jencks and M. Phillips, eds. (Washington, DC: The Brookings Institute) pp. 149-181.

Hernstein, Richard J., and Charles Murray. 1994. The Bell Curve: Intelligence and Class Structure in American Life. The Free Press.

Heyns, Barbara. 1978. Summer Learning and the Effects of Schooling. New York: Academic Press.

Humphreys, Lloyd. 1988. "Trends in Levels of Academic Achievement of Blacks and Other Minorities." Intelligence 12: pp. 231-260.

Jencks, Christopher, and Meredith Phillips. 1998. “America's Next Achievement Test: Closing the Black-White Test Score Gap," American Prospect, 0(40):44-53, Sept-Oct.

Jensen, Arthur. 1969. "How Much Can We Boost IQ and Scholastic Achievement?" Harvard Educational Review, 39, pp. 1-123.

Jensen, Arthur. 1973. Educability and Group Differences. New York: Free Press.

Jensen, Arthur. 1998. The G Factor: The Science of Mental Ability. Greenwood Publishing Group

Jones, Lyle V, Burton, Nancy, and Davenport, Ernest. 1982. Mathematics Achievement Levels of Black and White Youth. Chapel Hill: University of North Carolina, L.L. Thurstone Psychometric Laboratory.

Kaufman A., and Kaufman N. 1983. K-ABC: Kaufman Assessment Battery for Children. Circle Pines, MN: American Guidance Services.

Kincheloe, Joe., Steinberg, Shirley, and Gresson, Aaron. 1997. Measured Lies: The Bell Curve Re-examined. St. Martins Press.

Krohn, E., and Lamp, R., 1989. "Current Valiity of the Stanford-Binet Fourth Edition and KABC for Head Start Children.” Journal of Psychology, 27, pp. 59-67.

Li, Kai and Dale J. Poirier, "The Roles of Birth Inputs and Outputs in Predicting Health, Behavior, and Test Scores at Age Five or Six,” Working Paper, 2001.

Lightfoot, Sara., 1978. Worlds Apart: Relationships between Families and Schools. New York: 
Basic Books.

Mayer, Susan E. 1997. What Money Can't Buy: Family Income and Children's Life Chances. Harvard University Press.

Naglieri, J. 1986. "WISC-R and K-ABC comparison for matched samples of Black and White Children." Journal of Social Psychology, 24, pp. 81-88

Neal, Derek and William R. Johnson. 1996 "The Role of Pre-Market Factors in Black-White Wage Differences," Journal of Political Economy, vol. 104, pp. 869-895.

Neal, Derek. 1997. "The Effects of Catholic Secondary Schooling on Educational Achievement," Journal of Labor Economics, 15, pp. 98-123.

O’Neill, June. 1990. "The Role of Human Capital in Earnings Differences between Black and White Men.” Journal of Economic Perspectives 4(4):25-46.

Phillips, Meredith. 2000. "Understanding Ethnic Differences in Academic Achievement: Empirical Lessons from National Data." In David Grissmer and Michael Ross (eds.), Analytic Issues in the Assessment of Student Achievement. pp. 103-132. Wachington D.C.: U.S. Department of Education, National Center for Education Statistics.

Phillips, Meredith, Jeanne Brooks-Gunn, Greg J. Duncan, and Pamela K. Klebanov. 1998. "Family Background, Parenting Practices, and the Black-White Test Score Gap," pp. 103-145 in The Black-White Test Score Gap, C. Jencks and M. Phillips, eds. (Washington, DC: The Brookings Institute).

Phillips, Meredith, Crouse, James, and Ralph, John. 1998. "Does the Black-White Test Score Gap Widen After Children Enter School?" in The Black-White Test Score Gap, C. Jencks and M. Phillips, eds. (Washington, DC: The Brookings Institute) pp. 229-272.

Rodgers, William and Spriggs, William. 1996. "What Does AFQT Really Measure: Race, Wages, Schooling and the AFQT Score." The Review of Black Political Economy 24 (4): 13-46.

Scarr, Sandra. 1981. Race, Social Class and Individual Differences in I. Q. Lawrence Erlbaum Associates Pub.

Steele, C., and Aronson, J., 1998. "Stereotype Threat and the Test Performance of Academically Successful African Americans." in The Black-White Test Score Gap, C. Jencks and M. Phillips, eds. (Washington, DC: The Brookings Institute) pp. 401-30. 